\section{An Investigation On Job Performance}

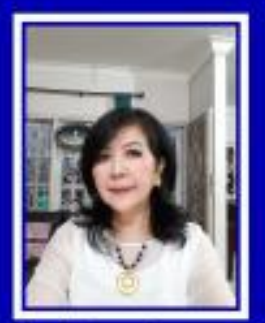

Dhenok Darwanti, SE., MM, merupakan seorang pengajar aktif di ITB Swadharma dan Universitas Borobudur Jakarta. la pernah menempuh pendidikan magister di Universitas Borobudur Jakarta. Lahir di Yogyakarta dan tumbuh menjadi seorang dengan segudang keahlian dan pengalaman, antara lain pernah menjadi Sekretaris di Asia Oceania Organization di Brasilia, pernah tergabung dalam anggota Cooking Club di Brasilia. Menjabat sebagai Ketua Organisasi Dharma Wanita KBRI Brasilia, ernah belajar Bahasa Portugis di Brasilia Universidade, pernah menghadiri pelantikan Presiden Brasil Luiz Inacio Lula da Silva dan pelantikan Presiden Peru Alejandro Toledo. Pernah menjadi ketua Ladies Program kunjungan Presiden Abdulrahman Wahid ke Brasil. Pernah belajar Bahasa Perancis di Jenewa Switzerland dan menjadi anggota United Nations Women's Guild. Pernah menjadi guru Sekolah Dutika Nanda di PTRI Jenewa. Pernah tinggal dan menetap di Switzerland selama 3 tahun 6 bulan. Pernah mengunjungi berbagai negara diantaranya, Eropa (Belanda, Jerman, Austria, Belgia, Perancis, Andora, Hungaria, Portugis, UK, Bratislava, Czeck, Italy, Vatikan, San Marino), Amerika, Canada, Brasil, Uruguay, Paraguay, Argentina, Venezuela, Chile, Peru, Korea, Malaysia, Singapura, Thailand.

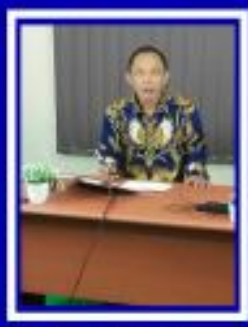

Edi Mulyanto, saat ini berprofesi sebagai dosen tetap Yayasan pada Universitas Pamulang di program studi Pendidikan Ekonomi. Kariernya diawali sebagai praktisi di beberapa perusahaan besar swasta nasional. Selain pernah di luar negeri, pengalamannnya diperoleh selama hampir 20 tahun mengelola bidang keuangan dan SDM (Sumber Daya Manusia) di berbagai proyek strategis dan mercusuar yang tersebar di berbagai provinsi di Indonesia. Pendidikan formal dan informal diperoleh diantaranya dari LPPM, Universitas Trisakti dan Universitas Indonesia. Sebagai dosen, Edi Mulyanto telah menerbitkan berbagai buku dan artikel jurnal nasional. Selain itu, beliau juga aktif menulis artikel dan opini di berbagai surat kabar lokal maupun nasional.

\section{Dhenok Darwanti, SE., MM Edi Mulyanto, SE., M.Ec}

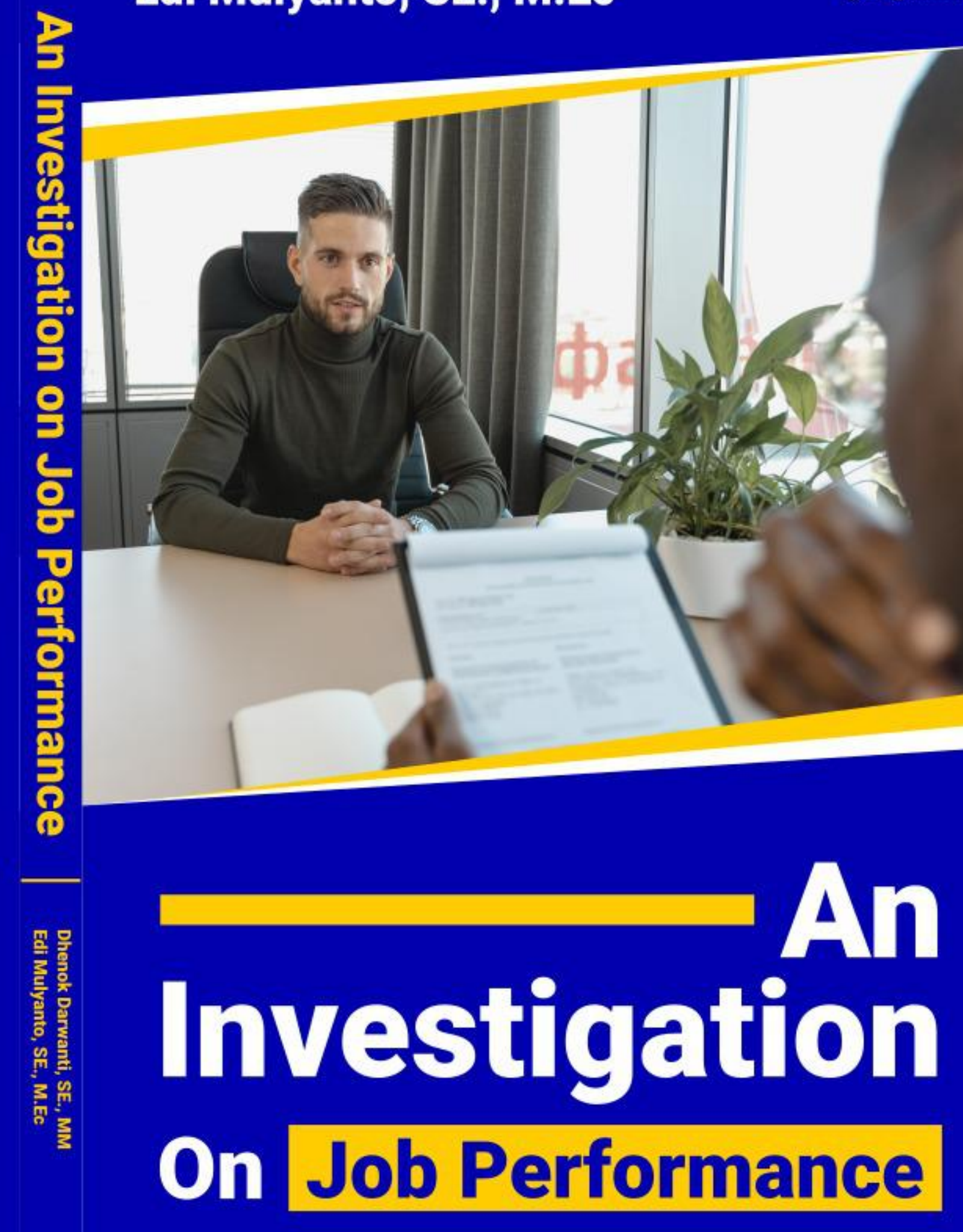


An Investigation on Job Performance

Dhenok Darwanti, SE., MM

Edi Mulyanto, SE., M.Ec

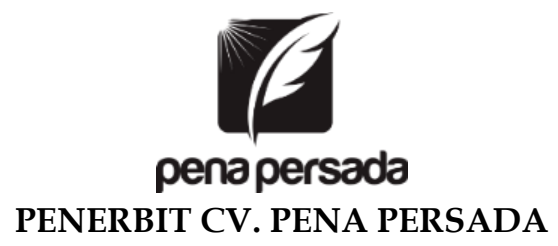




\title{
An Investigation on Job Performance
}

\author{
Penulis: \\ Dhenok Darwanti, SE., MM \\ Edi Mulyanto, SE., M.Ec
}

ISBN:

Editor:

Design Cover:

Arsyie Kania Rakhma

Layout:

Mutolib

\section{Penerbit CV. Pena Persada}

Redaksi:

Jl. Gerilya No. 292 Purwokerto Selatan, Kab. Banyumas Jawa Tengah

Email: penerbit.penapersada@gmail.com Website: penapersada.com Phone: (0281) 7771388

\section{Anggota IKAPI}

All right reserved

Cetakan pertama: 2021

Hak Cipta dilindungi oleh undang-undang. Dilarang memperbanyak karya tulis ini dalam bentuk apapun tanpa izin penerbit 


\section{KATA PENGANTAR}

Berkat rahmat dari Tuhan Yang Maha Kuasa, akhirnya penulis dapat menyelesaikan buku ini. Metodologi dan penulisan ilmiah ini merupakan hasil investigasi kajian lapangan yang penulis sajikan dalam bentuk buku dengan judul " $A \boldsymbol{n}$ Investigation on Job Performance". Dengan rendah hati, penulis menghaturkan terima kasih kepada pihak-pihak yang terkait selama proses sampai penyelesaian buku ini.

Yang melatarbelakangi penulisan buku ini ada beberapa hal diantaranya mengenai kurangnya perhatian atasan terhadap pemberian bonus PT. XY. Penulis juga menemukan fakta di lapangan bahwa karyawan bekerja melebihi batas jam kerja. Selain itu masih rendahnya tingkat kedisiplinan pegawai dalam mentaati peraturan yang berlaku dan masih rendahnya kesadaran perlunya absensi karyawan PT. XY. Melalui latar belakang inilah penulis mencoba membahas secara rinci aspek pengelolaan sumberdaya manusia pada PT. XY.

Penulis tentu menyadari jika buku ini isinya masih belum cukup sempurna. Penulis mengharapkan kritik maupun saran guna penyempurnaan buku ini. Semoga Tuhan YME membalas jasa semua pihak yang telah membantu penyelesaian buku ini, dengan harapan bermanfa'at untuk pengembangan ilmu pengetahuan dalam rangka mencerdaskan kehidupan bangsa. 


\section{DAFTAR ISI}

KATA PENGANTAR ...................................................................... iii

DAFTAR ISI ....................................................................................

BAB I PENDAHULUAN ................................................................. 1

A. Perlunya Motivasi Karyawan di Perusahaan .................... 1

B. Penurunan Kinerja Karyawan........................................... 2

BAB II PENGELOLAAN (MANAJEMEN) SUMBER DAYA

MANUSIA ........................................................................... 9

A. Pengertian Manajemen.................................................... 9

B. Dasar-Dasar Manajemen................................................... 10

C. Sistem-Sistem Manajemen ............................................... 10

D. Fungsi-Fungsi Manajemen .............................................. 11

E. Unsur - unsur Manajemen .............................................. 12

F. Manajemen Sumber Daya Manusia ................................. 13

BAB III KONSEP MOTIVASI, STRES KERJA DAN KINERJA .....19

A. Motivasi.......................................................................... 19

B. Stres Kerja …................................................................. 23

C. Kinerja ….................................................................... 26

BAB IV MOTIVASI DAN KINERJA KARYAWAN DI PT. XY ....29

A. Profil PT. XY .......................................................................... 29

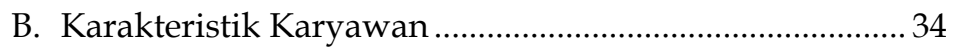

BAB V PENUTUP ...................................................................... 51

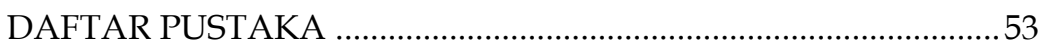




\section{BAB I \\ PENDAHULUAN}

\section{A. Perlunya Motivasi Karyawan di Perusahaan}

Pengembangan dan pengelolaan SDM yang terencana, terlatih dan berkesinambungan menjadi factor penting bagi pertumbuhan sebuah perusahaan. Pada akhirnya kondisi tersebut akan menjadikan perusahaan mampu memcapai tujuan yang diinginkan karena memiliki konsep "the right man on right place" yaitu orang tepat berada di tempat yang tepat. Jika kondisi seperti ini terjadi pada perusahaan, maka memudahkan perusahaan menjalankan operasinya, karena di dukung SDM yang handal dan berkomitmen tinggi

Apalagi di era globalisasi yang semakin kompetitif seperti sekarang ini, perusahaan dituntut mampu menghadapi berbagai tantangan yang ada baik secara nasional maupun global. Untuk mencapai kinerja yang tinggi seseorang atau karyawan harus memiliki motivasi juga untuk berprestasi dan unggul dalam pekerjaannya.

Perlunya evaluasi dan kebijakan pemberian "reward and punishment" bagi perusahaan tampak dari hasil kinerja setiap karyawan di dalam perusahaan tersebut. Sehingga diharapkan karyawan mempunyai motivasi bekerja dan berprestasi yang tinggi guna tercapainya tujuan perusahaan. Menurut Anwar P.M dalam Ridhotullah, S (2015:291) "Motivasi merupakan kondisi atau energi yang mengerakkan diri pegawai yang terarah atau tertuju untuk mencapai tujuan oraganisasi perusahaan." Motivasi sangat penting, karena pimpinan tingkat menengah atau puncak mendelegasikan tanggungjawab pekerjaan kepada bawahannya agar dapat dikerjakan secara baik dan benar, efisien dan efektif terintegrasi denagn tujuan yang di inginkan perusahaan. Kurangnya semangat karyawan bisa dilihat dari kedisiplinan dia dalam bekerja, ketepatan dia dalam menyelesaikan pekerjaan dan keinginan untuk 
berprestasi dalam bekerja. Jika karyawan tidak memiliki motivasi, karyawan dianggap tidak bisa memenuhi tugasnya sebagai pekerja.

Mmenurunnya kinerja karyawan dalam bekerja dan rendahnya minat untuk maju beprestasi dapat disebabkan berbagai factor. Salah satu penilaian yang dapat dilakukan perusahaan yakni melalui evaluasi secara periodic atau berkala, agar selalu dapat dimonitor perkembangan kinerjanya dan perlunya dilakukan pengembangan diri, penyesuaian pendapatan atau jabatan, baik yang diakibatkan karena factor inflasi maupun juga kinerja karwayan.

Menurut Sunyoto (2015:54) "stres merupakan sesuatu yang menyangkut interaksi antara individu dan lingkungan yaitu interaksi antara simultan dan respon. Jadi stres adalah konsekuensi setiap tindakan dan situasi lingkungan yang menimbulkan tuntutan psikologi dan fisik yang berlebihan." Stres kerja berpotensi timbul, jika kesenjangan antara kemampuan individu dengan tuntutan-tuntutan dari pekerjaannya

Namun disisi lain stres kerja juga bisa dipengaruhi dengan masalah perusahaan dan mengakibatkan kinerja yang dihasilkan tidak maksimal.

\section{B. Penurunan Kinerja Karyawan}

Sukses dan tidaknya perusahaan mencapai tujuan, tidak terlepas dari andil kontribusi, peranan dan kinerja para karyawannya. Jadi salah satu unsur yang berpengaruh amat penting terhadap tingkat keberhasilan suatu perusahaan itu sendiri yaitu performance karyawan. Karyawan yang terampil dan cakap berkerja, adalah menjadi harapan bagi perusahaan. Menurut Sutrisno (2015:172) “Kinerja karyawan adalah hasil kerja karyawan dilihat dari aspek kualitas, kuantitas, waktu kerja, dan kerja sama untuk mencapai tujuan yang sudah ditetapkan organisasi." Semua dapat berjalan optimal, apabila di dukung oleh SDM yang cakap dan terampil. 
PT. XY bergerak di bidang online shop. PT. XY memiliki toko online yang bernama sama yakni $X Y$, karyawan yang bekerja disana terdapat 67 orang yang berbeda bagiannya.

Hasil pengamatan langsung penulis, motivasi karyawan PT. XY mengalami kinerja yang menurun, hal ini yang dirasakan masih rendahnya tingkat upah yang diterima belum mencukupi kebutuhan utama (sandang, pangan, papan) mereka. Bahkan mereka hanya mampu untuk membayar hutang untun memenuhi kebutuhan sehari-hari bersama keluarga saja.. Untuk jasa layanan facebook, karyawan yang bersangkutan hanya mendapatkan gaji pokok saja, sementara bagi karyawan lainnya, hanya memperoleh bonus yang nilainya tidak sebanding linear kinerja mereka. Selain itu karyawan juga belum memperoleh rasa aman sepenuhnya. Kondisi tersebut, dapat dilihat dari tunjangan kesehatan karyawan yang belum sesuai harapan, bahkan tidak juga diberikan jaminan asuransi kesehatan maupun ketenagakerjaan. Tentu hal ini semua berdampak menurunnya motivasi kerja karyawan. Dampaknya, absensi meningkat dimana banyak karyawan yang sering terlambat saat jam kerja perusahaan, sering izin tidak mmasuk bekerja dengan berbagai alasan, tidak tepat waktu dalam menyelesaikan kerjaan (on time), dan karyawan tidak termotivasi/bergairah untuk berprestasi. Kondisi demikian ini, tampak seperti yang tertera di tabel 1.1 sebagai berikut :

Tabel 1.1

Data Absensi Karyawan Terlambat di PT. XY

\begin{tabular}{|l|c|c|c|}
\hline \multirow{2}{*}{ Bulan } & \multicolumn{3}{|c|}{ Keterangan } \\
\cline { 2 - 4 } & Terlambat & Alfa & Ijin \\
\hline Mei & 23 & 4 & 6 \\
\hline Juni & 26 & 5 & 8 \\
\hline Juli & 30 & 8 & 11 \\
\hline
\end{tabular}

dari bulan Mei-Juli 2019

Sumber : Data Absensi CV Muslim Galeri Indonesia 
Tabel 1.1 diatas menunjukkan bahwa tingkat keterlambatan, alfa dan ijin dari bulan mei hingga juni semakin meningkat. Hal tersebut menunjukan menurunnya tingkat motivasi karyawan dalam bekerja, beberapa faktor mempengaruhi motivasi karyawan menurun. Seperti kurangnya penghargaan dari perusahaan terhadap karyawan yang berprestasi, seperti tidak ada jenjang karir. Kebutuhan sosial, untuk persahabatan dan pertemanan kurang erat karena banyak yang saling menggunjing satu sama lain, tetapi tidak semuanya demikian. Kebutuhan aktualisasi diri, dalam hal mengeksplor kemampuan, kurang di beri wadah, karena atasan hanya memberikan mandat kepada karyawan yang sudah lama kerja di perusahaan tersebut. Karyawan juga sangat pasif ketika atasan meminta ide atau saran dalam diskusi.

Faktor-faktor penyebab lainnya, karyawan PT. XY juga disebabkan oleh beban kerja yang membuat stress. Secara umum, hampir setiap karyawan mempunyai beban kerja yang menimbulkan stress. Sebagai contoh pada karyawan bagian customer service yang bertugas melayani konsumen. Sistem penjualan yang diterapkan perusahaan dengan cara pembayaran diterima perusahaan kemudian, setelah barang terkirim kepada konsumen. Di sisi lain, terdapat beberapa kemungkinan pembayaran mpara konsumen yang tidak memenuhi kewajibannya (wan prestasi). Kondisi demikian menjadikan beban moril bagi karyawan, jika terjadi gagal bayar oleh para konsumennya. Sementara barang sudah terlanjur berada pada pihak konsumen dan tidak di retur atau dikembalikan kepada perusahaan.

Usaha untuk mengejar pembayaran konsumen yang gagal bayar, menyebabkan karyawan sering bekerja diluar waktu bekerja mereka. Bahkan sering karywan menemeui konsumen yang tidak mau memenuhi kewajibannya. Jika terjadi keadaan yang demikian, maka menjadi tanggungjawab karyawan tersebut. Customer service dituntut agar dapat mengendalikan konsumen dapat memenuhi kewajibannya. 
Selain customer service, karyawan di bagian yang lainnya juga seperti di bagian IT, mengalami hal yang serupa, mereka terpaksa harus bekerja diluar jam operasioanl perusahaan. Kondisi yang demikian tentulah memprihatinkan. Mereka terpaksa bekerja hingga larut malam, dikarenakan wajib merakit produk yang akan dijual perusahaan. Hal tersebut mengakibatkan konflik terjadi dengan pembeli dan terkadang customer service harus menggunakan kalimat yang cukup keras dalam menagih. Semua nya tentu saja tidak mudah, mengingat penjual dan pembeli melakukan transaksi hanya melalui dunia maya. Selain itu lingkungan perusahaan yang berlokasi dekat dengan perumahan warga yang terkadang ada warga yang tidak suka dengan kehadiran perusaan ini. Di samping itu juga, untuk jenjang karir tidak ada sehingga membuat karyawan malas-malasan dalam bekerja. Faktor tersebut sangat mengganggu kinerja karyawan PT. XY. Dan setiap bulan pasti ada saja customer yang tidak mau membayar barang yang sudah dipesan. Omset menurun dan berimbas kepada semua karyawan. Tak hanya itu saja ketika barang yang dijual tidak memiliki stok yang banyak tapi orderan yang melibihi stok membuat customer service dan perusahaan sedikit kalang kabut, karna tidak mungkin perusahaan mengecewakan customer dengan cara menolak orderan. Tentu saja langkah yang diambil harus cepat, perusahaan harus mensiasatinya dengan cara $P O$ (pre order) terlebih dahulu. Dan sistem tersebut sedikit membantu tetapi merugikan beberapa pihak. 
Tabel 1.2

Total Tagihan Customer Service Facebook di PT. XY

Periode Mei-Juli 2019

\begin{tabular}{|l|c|c|c|}
\hline \multirow{2}{*}{ Keterangan } & \multicolumn{3}{|c|}{ Bulan } \\
\cline { 2 - 4 } & Mei & Juni & Juli \\
\hline Total Tagihan & 70 orang & 90 orang & 110 orang \\
\hline $\begin{array}{l}\text { Target yang } \\
\text { harus dicapai } \\
(50 \%)\end{array}$ & 35 orang & 45 orang & 55 0rang \\
\hline $\begin{array}{l}\text { Target yang } \\
\text { terealisasi }\end{array}$ & 20 orang & 35 orang & 40 orang \\
\hline Keterangan & $\begin{array}{c}\text { Belum } \\
\text { tercapai }\end{array}$ & Belum tercapai & $\begin{array}{c}\text { Belum } \\
\text { tercapai }\end{array}$ \\
\hline
\end{tabular}

\section{Sumber : data diolah}

Dari tabel diatas dapat dilihat, banyak sekali customer service yang belum bisa memenuhi target dalam menagih pembeli yang tidak amanah, hal tersebut mengakibatkan customer service mengalami tekanan karena tidak bisa menyelesaikan pekerjaan dengan baik akibatnya kinerja karyawan menurun. Lingkungan Kerja juga dapat menyebabkan stress dimana dari hasil pengamatan penulis, lingkungan kerja di CV Muslim Indonesia sedikit sumpek, masih banyak barang yang berada tidak pada tempatnya. Selain itu untuk Jenjang karir disana tidak ada, dimana penulis menemukan masih banyak karyawan yang memegang posisi yang sama padahal ia sudah lama bekerja tanpa ada kenaikan jabatan.

Motivasi kerja yang menurun, stress kerja yang meningkat dapat mengakibatkan kinerja karyawan menurun. Kinerja karyawan yang menurun mengakibatkan kinerja perusahaan mengalami penurunan seperti Tabel 1.3 dibawah ini : 
Tabel 1.3

Realisasi Penjualan Bulan Mei-Juli 2019

\begin{tabular}{|c|c|c|c|}
\hline Bulan & Target & Realisasi & Presentase \\
\hline Mei & 757.565 .303 & 697.869 .157 & $92.12 \%$ \\
\hline Juni & 765.199 .200 & 701.075 .507 & $91.62 \%$ \\
\hline Juli & 800.126 .211 & 720.273 .615 & $90.02 \%$ \\
\hline
\end{tabular}

Sumber : data diolah

Berdasarkan data diatas dapat disimpulkan penjualan masih jauh dengan target yang di tetapkan. Semakin bulan semakin menurun penjualan yang dialami, ada beberapa faktor yang mempengaruhi, diantaranya kurangnya tanggung jawab yang dimiliki karyawan, menurunnya minat pembeli, dan biaya iklan yang tidak menentu. Selain itu kinerja karyawan yang menurun dilihat dari kualitas yang menurun. Dimana karyawan kurang teliti dalam melakukan pekerjaan,P seperti masih sering salah tempel resi pengiriman, salah pengiriman barang dan sebagainya. Banyak karyawan yang tiadak bekerja sesuai target waktu yang ditetapkan perusahaan. Kondisi ini disebabkan karena sudah terbiasa menunda-nunda waktu menyelesaikan pekerjaannya. Akibatnya, banyak pekerjaan yang harus diselesaikan dan tidak mencapai target yang ditetapkan perusahaan.

Dari pengamatan langsung penulis, terlihat banyak karyawan yang belum memahami dan mengerti tentang hak dan kewajibannya sebagai karyawan yang bekerja di perusahaan tersebut. Pada jam waktu bekerja, sering karyawan memanfaatkannya waktu tersebut dengan kebiasaan mereka masing-masing, seperti : main game, melihat youtube, ngobrol sana-sini dan bahkan mereka memanfaatkan waktu istirahat lebih lama dari ketentuan waktu yang berlaku perusahaan. Di sisi lain, karyawan belum terlihat dapat bersinergi (bekerjasama) dalam menyelesaikan pekerjaan di perusahaan tersebut. Kondisi seperti ini, diperparah lagi jika timbul suatu 
masalah di perusahaan. Mereka cenderung menunggu perintah dari atasan, tanpa adanya inisiatif dari diri karyawan tersebut.

Kurangnya motivasi bekerja dan tingkat stres yang di alami karyawan, berdampak mempengaruhi kinerjanya di tempat mereka bekerja. Dari latar belakang tersebut diatas, penulis mempunyai ketertarikan untuk membahas dampak secara psikologis, terutama dari motivasi serta stres kerja yang terkait dengan kinerja karyawan pada PT.XY. 


\section{BAB II \\ PENGELOLAAN (MANAJEMEN) SUMBER DAYA MANUSIA}

\section{A. Pengertian Manajemen}

Manajemen dapat diartikan sebagai seni menjalankan suatu kegiatan/pekerjaan melalui orang lain dalam rangka mencapai tujuan sesuai yang ditentukan. Manajemen dapat dikatakan baik, apabila menerapkan fungsi-fungsi manajemen. Sedangkan yang disebut fungsi-fungsi manajemen itu sendiri, terdiri atas : planning atau perencanaan, organizing atau pengorganisasian, actuating atau menggerakkan dan controlling atau pengendalian.

Definisi manajemen menurut ahli :

1. Menurut M. Manullang (2018:2) “ manajemen adalah seni dan ilmu perencanaan, pengorganisasian, penyusunan, pengarahan dan pengawasan sumber daya manusia untuk mencapai tujuan yang sudah ditetapkan."

2. Menurut Harold Koontz dan Cyril O'Donnel dalam buku Malayu S.P Hasibuan (2018:3) "management is getting things done trough people. In bringing about this coordinating of group activity, the manager, as a manager plans, organize, staffs, direct and control the activities other people." (yang dimaksud manajemen itu adalah menyelesaikan sesuatu melalui orang-orang. Dalam melaksanakan koordinasi kegiatan kelompok ini, manajer, sebagai manajer merencanakan, mengatur, mengatur, mengarahkan dan mengendalikan kegiatan orang lain).

3. Menurut pendapat Malayu S.P. Hasibuan (2019:1) diuraikan "manajemen adalah ilmu dan seni mengatur proses pemanfaatan sumber daya manusia dan sumber-sumber lainnya secara efektif dan efisien untuk mencapai suatu tujuan tertentu" 
Dari pengertian tersebut, ditarik kesimpulan bahwa manajemen merupakan sebuah proses kegiatan mulai dari planning (perencanaan), kemudian organizing (pengorganisasian), actuating (menggerakkan) sampai dengan controlling (pengendalian). Proses ini dilakukan agar dapat mencapai tujuan bersama yang ditetapkan perusahaan.

\section{B. Dasar-Dasar Manajemen}

Di dalam manajemen terdapat antara lain :

1. Unsur kerja sama tim di dalam organisasi perusahaan.

2. Unsur tujuan yang hendak dicapai oleh suatu perusahaan.

3. Unsur division of work (pembagian kerja).

4. Unsur tata tertib dan peraturan di dalam organisasi perusahaan.

5. Unsur perencanaan di dalam organisasi perusahaan.

6. Unsur struktur organisasi perusahaan.

\section{Sistem-Sistem Manajemen}

Sistem atau gaya manajemen yang biasa diterapkan oleh seorang manajer di dalam mengelola atau memimpin suatu organisasi sebuah perusahaan, memiliki gaya yang berbeda-beda. Hal ini tergantung dari masing-masing budaya yang dimiliki perusahaannya serta sikap leadership dari seorang manajer yang memimpin organisasi pada perusahaan tersebut.

Sistem manajemen terdiri dari :

1. Paternalistic Management (Manajemen Kebapakan)

Pada sistem manajemen kebapakan, dapat diartikan bahwa bawahan akan selalu meniru serta mengikuti perintah atasan yang dianggap sebagai symbol dan tauladan dalam segala aspek kegiatan perusahaan, baik cara mulai gaya bekerja maupun dalam mengatasi berbagai persoalaan yang kemungkinan timbul. Perilaku maupun gaya memimpin atasan selalu akan menjadi contoh bagi bawahan. 


\section{Closed Management (Manajemen Tertutup)}

Dalam manajemen tertutup (manajemen tertutup), manajer dalam mengelola sistim informasi sangat terbatas pada kalangan tertentu dan merahasiakan informasi yang dianggap penting oleh perusahaan agar tidak sampai diketahui oleh bawahan.

3. Manajemen terbuka (Open Management)

Manajemen terbuka, merupakan kebalikkan dari manajemen tertutup. Pengelolaan sistim informasi perusahaan tidak selalu dibatasi untuk level tertentu saja. Perusahaan menganggap perlu dan penting untuk memberikan informasi kepada bawahan, dengan harapan dapat diketahui bawahan.

4. Manajemen Demokrasi (Democratic Management)

Gaya manajemen demokrasi, mirip dengan gaya manajemen terbuka. Manajemen bersifat terbuka dan melibatkan bawahan dalam pertemuan-pertemuan formal perusahaan.

\section{Fungsi-Fungsi Manajemen}

Secara umum manajemen memiliki banyak definisi. Konsep manajemen yang paling umum dan banyak diterapkan yaitu, melakukan pekerjaan melalui orang lain (dalam hal ini karyawan) agar tujuan perusahaan dapat dicapai sesuai yang ditentukan. Berikut adalah fungsi-fungsi manajemen menurut Drs. P. Siagian (2018:38):

1. Planning

Planning berkaitan dengan rencana dan pendefinisian sasaan untuk kinerja organisasi atau perusahaan dimasa depan serta penetapan tugas-tugas dan sumber daya yang akan digunakan untuk mencaai tujuan yang telah ditetapkan.

2. Organizing

Organizing yaitu fungsi manajemen yang berkaitan erat dengan pengorganisasian yang ditunjuk untuk pendeligasian wewenang bagi karyawan. 


\section{Motivating}

Motivating yaitu, perilaku seseorang yang dipengaruhi dan dirangsang oleh keinginan, pemenuhan kebutuhan serta tujuan untuk kepuasannya.

\section{Controling}

Controling erat kaitannya dengan pengawasan terhadap karyawan agar kegiatasn karyawan tetap berada dalam koridor yang benar untuk mencapai tujuan dari suatu organisasi atau perusahaan.

\section{Evaluation}

Evaluation mengevaluasi atau memberikan nilai terhadap karyawan secara terprogram.

\section{E. Unsur - unsur Manajemen}

Manajemen memiliki unsur-unsur : man, money, methode, machine, materials dan market, yang perlu dikelola secara efektif dan efisien oleh perusahaan, agar perusahaan tidak menderita kerugian.

1. Manusia (Man), unsur manusia yang bertindak menjalankan dan mengelola aktivitas sesuai dengan tujuan perusahaan (planning, organizing, actuating dan controlling).

2. Uang (Money), unsur uang merupakan komponen penting dalam perusahaan. Perusahaan dituntut dapat mengelola keuangan dengan baik, secara efisien dan efektif agar tidak terjadi pemborosan dan atau terjadi kerugian pada perusahaan.

3. Bahan-bahan (Material), unsur material merupakan bahan baku yang akan dimanfaatkan hasilnya secara optimal. Sehingga produk akhir yang diharapkan perusahaan dapat tercapai baik dari segi kualitas maupun kuantitasnya.

4. Cara pelaksanaan (Method), unsur metode merupakan sebuah sistem dalam menyelesaikan berbagai pekerjaan yang digunakan manajemen yang akan berdampak efisien dan efektif nya suatu pekerjaan di dalam perusahaan tersebut, agar dapat dicapai tujuan sesuai yang diharapkan oleh perusahaan secara optimal. 
5. Pasar (Market), unsur pasar menjadi penentu bagi kehidupan perusahaan. Tanpa sasaran pasar yang jelas, maka produk yang dihasilkan perusahaan tidak akan terjual dengan baik kepada konsumen, sesuai target yang ditentukan perusahaan.

6. Mesin (machine), unsur mesin menjadi vital dalam proses produksi. Penggunaan mesin dibutuhkan agar dapat efisien dan efektif dalam menghasilkan produk akhir perusahaan. Perusahaan perlu menyesuaikan perkembangan teknologi agar selalu dapat dikendalikan pemborosan bahan baku yang pada akhirnya akan mengurangi keuntungan penjualan perusahaan.

\section{F. Manajemen Sumber Daya Manusia}

1. Pengertian Manajemen Sumber Daya Manusia

Pengelolaan (manajemen) SDM pada hakekatnya merupakan unsur manusia yang di dalamnya mencakup aspek pengelolaan, pengembangan dan pembinaan yang berada di dalam lingkungan organisasi internal perusahaan. Pengelolaan yang baik terhadap sumber daya manusia akan mempermudah bagi perusahaan untuk tujuan tertentu yang di tetapkan.

Definisi Manajemen SDM menurut para ahli :

a. Pengertian MSDM Menurut Simamora, (2016 : 7) "Manajemen SDM adalah proses pendayagunaan seluruh sumber daya manusia yang dimiliki organisasi untuk mencapai tujuan yang telah ditetapkan. Proses yang dimaksud melibatkan organisasi, arahan, koordinasi, dan evaluasi orang-orang guna mencapai tujuan yang ditetapkan tersebut."

b. Pengertian Manajemen SDM menurut Mangkunegara (2016 : 7) "Manajemen SDM dapat didefinisikan sebagai suatu pengelolaan dan pendayagunaan sumber daya yang ada pada individu. Selanjutnya, dikemukakan bahwa MSDM merupakan suatu perencanaan, pengorganisasian, pengoordinasian, pelaksanaan dan 
pengawasan terhadap pengadaan, pengembangan, pemberian balas jasa, pengintegrasian, pemeliharaan dan pemisahan tenaga kerja dalam rangka mencapai tujuan organisasi."

c. Pengertian Manajemen SDM menurut Drs. H. Sadili Samsudin, M.M, M.Pd. (2018:7) "manajemen SDM siatu kegiatan pengelolaan yang meliputi pendayagunaan, pengembangan, penilaian, pemberian balas jasa bagi manusia sebagai individu angota organisasi atau perusahaan lain."

\section{Komponen MSDM}

Komponen SDM pada prinsipnya terdiri dari pengusaha (investor), bawahan (karyawan) dan pemimpin (manajer).

a. Pengusaha (investor)

Pengusaha merupakan orang yang memiliki capital (modal) yang diinvestasikan pada suatu usaha dengan tujuan memperoleh keuntungan.

b. Bawahan (Karyawan)

Karyawan merupakan asset bagi perusahaan. Karyawan bekerja yang akan menghasilkan kekayaan bagi suatu perusahaan. Karyawan yang cakap bekerja, akan menghasilkan output yang baik bagi perusahaan dimana tempat mereka bekerja. Peran karyawan tidak terlepas bagaimana perusahaan mengelolanya secara baik. Pembinaan dan pengembangan karier serta penghargaan terhadap karyawan yang tinggi, akan mendorong motivasi bekerja yang tinggi.

c. Pimpinnan (manajer)

Pimpinan memegang peranan penting dalam mengelola para karyawan di dalam organisasi perusahaan. Leadership yang baik, akan menjadi factor pendorong motivasi kepada bawahan dalam bekerja menjalankan tugas dan tanggung jawabnya. Pimpinan dituntut dapat 
selalu mengikuti perkembangan jaman dan menjadikan karyawan sebagai asset perusahaan.

3. Pendekatan Manajemen Sumber Daya Manusia (MSDM)

Mengelola manusia, bukan pekerjaan yang mudah. Perbedaan latar belakang, pendidikan, lingkungan serta budaya setiap manusia membentuk karakter dan kepribadian yang berbeda-beda pada setiap manusia. Kondisi demikian yang menjadi tantangan bagi seorang pimpinan dalam mengelola sumberdaya manusianya di dalam organisasi perusahaan.

Manajemen sumber daya manausia (SDM), dapat dilihat melalui beberapa pendekatan, antara lain :

a. Pendekatan sumber daya manausia

Dengan memperhatikan unsur HAM (Hak Azasi Manusia), pengelolaan SDM perlu dilakukan pengembangan, pembinaan dan apresiasi yang terus berkelanjutan, sesuai apa yang menjadi hak dan kewajiban masing-masing, baik karyawan maupun perusahaan.

b. Pendekatan manajerial

Model pendekatan manajerial dilakukan dengan mengedepankan serta membangun hubungan dan sinergi kerjasama yang baik dengan departemen lainnya, sesuai peran dan tanggung jawab masingmasing manajer atau pimpinan.

c. Pendekatan sistem

Model pendekatan sistem, menjadi kunci optimal dan tidaknya sebuah proses. Sistem yang dibangun dan terbentuk dengan baik, akan menciptakan hasil yang diharapkan perusahaan menjadi optimal, efisien dan efektif. 


\section{d. Pendekatan proaktif}

Model pendekatan proaktif memerlukan kesadaran yang tinggi, motivasi dan inisiatif dari masing-masing individu di dalam lingkungan internal perusahaan. Kondisi ini menuntut terciptanya kondisi yang tidak selalu harus menunggu perintah dari atasan jika menghadapi masalah dan memecahkan masalah yang timbul sewaktu-waktu baik di dalam maupun diluar lingkungan perusahaan.

4. Fungsi Dari Manajemen Sumber Daya Manusia (MSDM)

Secara fungsional, manajemen sumber daya manusia memiliki keterkaitan diantara satu dengan yang lainnya. Fungsi MSDM dibagi menjadi 2 diantaranya, yaitu:

a. Managerial Function (Fungsi Manajerial)

Adalah fungsi dari manajemen yang berkaitan langsung terhadap fungsi planning (perencanaan), fungsi organizing (pengorganisasian), fungsi actuating (menggerakkan) dan fungsi controlling (pengendalian), dijelaskan sebagai berikut :

1) Fungsi planning (perencanaan), yaitu melaksanakan tugas dalam hal merencanakan kebutuhan, pengadaan, pengembangan dan pemeliharaan SDM. Dalam hal ini adalah merencanakan karir bagi para karyawan (tenaga kerja).

2) Fungsi organizing (pengorganisasian), adalah mengorganisir dengan membentuk struktur dan hubungan antara tugas yang harus dikerjakan oleh tenaga kerja yang telah dipersiapkan. Struktur dan hubungan yang dibentuk, harus disesuaikan dengan situasi dan kondisi organisasi yang bersangkutan. Perlu diperhatikan dalam fungsi pengorganisasian ini adalah menempatkan orang secara benar, pada tempat yang benar dan pada waktu yang benar dengn istilah "the rightman in the right place, in the right time". 
3) Fungsi actuating (menggerakkan), ialah memberikan support/dorongan menciptakan kemauan kerja yang dilaksanakan secara efektif dan efesien. Termasuk dalam hal ini adalah fungsi memotivasi karyawan agar dari waktu kewaktu dapat bekerja dengan baik. Prinsip yang harus dipegang adalah: "hari esok harus lebih baik dengan hari ini".

4) Fungsi controlling (pengendalian), yaitu dilakukan dengan membuat pengawasan dan pengendalian atas kegiatan terhadap rencana yang ditetapkan. Hal ini bertujuan untuk mengetahui, apakah perusahaan telah berjalan pada jalan yang benar, atau telah menyimpang dari rencana semula. Jika menyimpang, maka pihak manajemen segera meluruskan agar perusahaan tetap eksis dan menguntungkan.

Dari beberapa fungsi yang telah dikemukakan di atas, merupakan fungsi umum dari manajemen suatu organisasi.

b. Fungsi Operasional

Merupakan sebuah fungsi yang berhubungan secara langsung dengan operasional SDM di dalam organisasi, yang antara lain meliputi : proses rekrutmen, proses seleksi, proses penempatan dan pengangkatan, proses pelatihan dan proses pengembangan, proses kebijakan kompensasi, proses pemeliharaan dan juga tahap pemutusan hubungan kerja. Berapa ahli yang mengeluarkan pendapat tentang fungsi operasional MSDM antara lain :

1) Perencanaan SDM (sumber daya manusia) meliputi : perencanaan tentang kebutuhan organisasi pada masa yang akan datang.

2) Penyusunan tenaga kerja dan penilaian prestasi tenaga kerja Meliputi penarikan seleksi, penempatan dan indoktrinasi. 
3) Pelatihan dan pengembangan yaitu pelatihan yang dimaksud meliputi pelatihan yang bersifat manajerial ataupun pelatihan yang sifatnya operasional.

4) Kompensasi upah dan gaji sering disebut kompensasi tangible yang maksudnya dapat dengan mudah diukur.

5) Kesehatan dan keamanan, merupakan fasilitas kesehatan yang diberikan perusahaan terhadap karyawan. Sehingga karyawan merasa bahwa keamanan kesehatannya diperhatikan oleh perusahaan.

6) Hubungan perburuhan Yaitu dicapai melalui persetujuan dan perundingan secara kolektif.

7) Penilaian personal, meliputi perbedaan-perbedaan individu dan faktor yang dapat mempengaruhi MSDM. 


\section{BAB III \\ KONSEP MOTIVASI, STRES KERJA DAN KINERJA}

\section{A. Motivasi}

a. Pengertian Motivasi

Motivasi merupakan factor yang sangat penting di dalam perusahaan, agar karyawan bekerja secara optimal dan tercapainya tujuan perusahaan yang di tentukan.

Menurut Anwar P.M dalam Ridhotullah, S (2015:291) "Motivasi merupakan kondisi atau energi yang mengerakkan diri pegawai yang terarah atau tertuju untuk mencapai tujuan oraganisasi perusahaan".

Menurut pendapat Wayne F. Cascio dalam Malayu SP, Hasibuan (2018 : 11) " Motivasi adalah suatu kekuatan yang dihasilkan dari keinginan seseorang untuk memuaskan kebutuhannya, misal ; rasa lapar, haus dan dahaga".

b. Faktor Motivasi

Ada tujuh faktor-faktor motivasi diantaranya :

1. Promosi

Promosi adalah tawaran proses kenaikan jabatan/pangkat pada level tertentu yang lebih tinggi tanggungjawab dan wewenangnya di perusahaan.

2. Prestasi kerja

Merupakan hasil kinerja karyawan selama menjalankan tugas dan tanggungjawabnya di perusahaan.

3. Pekerjaan itu sendiri

Merupakan job description (uraian kerja) bagi masingmasing karyawan di perusahaan tempat mereka bekerja.

4. Penghargaan

Merupakan rewards yang diberikan oleh perusahaan kepada karyawan yang berprestasi terhadap perusahaan selama mereka bekerja. 
5. Tanggung jawab

Karyawan berkewajiban dan dituntut menjalankan pekerjaan sesuai tanggungjawab yang diberikan perusahaan kepada masing-masing karyawan, agar tujuan perusahaan dapat dicapai.

6. Pengakuan

Perusahaan secara periodik dapat melakukan evaluasi terhadap kinerja masing-masing karyawan dan dengan demikian dapat memberikan pengakuan sejauh mana kemampuan serta keahlian masing-masing karyawan dalam menjalankan tugas dan tanggungjawabnya kepada perusahaan.

7. Keberhasilan dalam bekerja

Tujuan perusahaan akan dapat dicapai sepanjang karyawannya dapat menjalankan tugas dan tanggungjawabnya dengan baik. Keberhasilan karyawan dalam bekerja, diperlukan motivasi atau dorongan yang terus berkelanjutan agar menimbulkan semangat bagi karyawannya.

c. Langkah-langkah Memotivasi

Langkah-langkah atau tahapan dalam memberikan motivasi karyawan dapat dilakukan antara lain :

1. Pimpinan wajib mengetahui apa yang dikerjakan oleh bawahannya

2. Pimpinan mampu memberikan suasana dan iklim kerja yang nyaman bagi semua karyawan perusahaan.

3. Pimpinan memberikan dorongan dan memenuhi segala kewajibannya, sehingga karyawan merasa terpenuhi kebutuhannya.

4. Pimpinan memberikan contoh yang dapat ditiru bagi karyawannya.

5. Pimpinan mampu mengendalikan karyawannya dengan baik.

6. Pimpinan dapat bertindak realistis dalam menghadapi dan menyelesaikan masalah. 
d. Tujuan Memberikan Motivasi

Diberikannya motivasi pada setiap karyawan, memiliki beberapa tujuan, antara lain :

1. Membangkitkan semangat gairah bekerja.

2. Meningkatkan tingkat kepuasan kerja.

3. Meningkatkan tingkat produktivitas.

4. Memiliki loyalitas terhadap perusahaan.

5. Memberikan kesadaran pentingnya disiplin bekerja.

6. Menciptakan lingkungan kerja yang baik.

7. Menumbuhkan kreativitas karyawan.

8. Meningkatkan tingkat kesejahteraan para karyawan.

9. Menumbuhkan rasa tangungjawab kepada karyawan

e. Sumber Motivasi

Sumber motivasi pada dasarnya dibedakan menjadi 2 (dua) bagian, yaitu : intrinsik dan ekstrinsik. Instrinsik adalah motivasi yang berasal dari dalam organisasi perusahaan. Sedangkan Ekstrinsik adalah motivasi yang bersumber dari luar lingkungan organisasi perusahaan.

1. Intrinsik

Intrinsik merupakan motivasi yang ditimbulkan akibat dari pengaruh internal organisasi perusahaan itu sendiri. Motivasi intrinsik tidak perlu rangsangan, karena sudah terbentuk kesadaran pada masing-masing karyawan dari pola kerja dan budaya kerja yang melekat pada lingungan internal organisasi perusahaan sehari-hari. Namun demikian, disadari bahwa setiap orang yang melakukan sesuatu di dorong oleh :

a) Interest (Minat), dari setiap individu.

b) Positive Attitude (Sikap Positif), dari setiap individu terhadap pekerjaan.

c) Needs (Kebutuhan), setiap individu yang berupaya minimal untuk dapat memenuhi kebutuhan dasarnya. 
2. Ekstrinsik

Ekstrinsik merupakan motivasi yang timbul akibat pengaruh atau dorongan dari luar lingkungan organisasi perusahaan.

\section{f. Indikator Motivasi}

Motivasi merupakan suatu bentuk kesadaran (abstrak) dari dalam diri seseorang, yang berpengaruh menimbulkan energy positif untuk melakukan sesuatu kegiatan (kongkrit). Menurut Maslow yang dikutip oleh Danang Sunyoto (2018:11) terdapat 5 indikator paling mendasar, antara lain :

1. Kebutuhan fisiologis

Merupakan basic needs (kebutuhan dasar) seseorang untuk tetap survive dalam kehidupannya. Basic needs ini adalah tingkat paling mendasar yang dibuat oleh Abraham Maslow.

2. Kebutuhan akan rasa aman

Orang akan mengambil risiko terhadap keamanan apabila kebutuhan dasarnya tidak terpenuhi.

3. Kebutuhan sosial

Selain 2 (dua) factor tersebut diatas, manusia pada hakekatnya membutuhkan lingkungan social sebagai bentuk ekspresi melalui persahabatan dan interaksi antar individu maupun kelompok.

4. Kebutuhan terhadap penghargaan

Faktor ini timbulnya akibat dari keinginan pengakuan dan penghargaan terhadap eksistensi dan aktivitas seseorang dalam lingkungannya.

5. Kebutuhan terhadap aktualisasi diri

Merupakan hierarki kebutuhan yang dibuat Abraham Maslow paling tinggi. Kebutuhan ini berhubungan dengan proses pengembangan diri terhadap potensi diri yang sesungguhnya yang dimiliki oleh seseorang. 


\section{B. Stres Kerja}

a. Hakekat stres kerja

Stres kerja pada hakekatnya merupakan kondisi dimana perasaan seorang karyawan sedang mengalami gangguan dan menjadi labil, Banyak factor yng memicu timbulnya stress kerja. Antara lain bisa disebabkan akibat terlalu berat beban kerja yang dipikulnya atau tidak normal terjadi. Beban ini biasanya menyebabkan seorang karyawan menjadi tidak stabil dan tidak tenang dalam menjalankan aktivitas.

Menurut Rivai (2014:724) "stres kerja adalah suatu kondisi ketegangan yang menciptakan adanya ketidak seimbangan fisik dan psikis, yang mempengaruhi emosi, proses berpikir dan kondisi seorang karyawan"

Sedangkan menurut Sunyoto (2015:54) "stres merupakan sesuatu yang menyangkut interaksi antara individu dan lingkungan yaitu interaksi antara simultan dan respon. Jadi stres adalah konsekuensi setiap tindakan dan situasi lingkungan yang menimbulkan tuntutan psikologi dan fisik yang berlebihan."

b. Penyebab Stres Kerja

Faktor-faktor penyebab terjadinya stres kerja, antara lain :

1. Akibat beban pekerjaan yang terlalu berat.

2. Target waktu kerja mendesak

3. Produktivitas kerja yang rendah.

4. Suasana bekerja yang kurang sehat.

5. Otoritas pekerjaan yang tidak memadahi dengan tanggung jawabnya

6. Konflik di dalam internal organisasi perusahaan.

7. Manajemen SDM yang tidak baik. 
c. Pendekatan Stres Kerja

Beberapa pendekatan stres kerja, antara lain :

1. Dukungan sosial

Pendekatan yang dilakukan melalui kegiatan, tujuannya agar dapat memberikan kepuasan sosial kepada para karyawan. Contoh : dengan bermain game, membuat lelucon..

2. Melalui meditasi

Melalui meditasi karyawan berkonsentarsi kepada alam pikiran, rileks, menetralisir emosi. Hal ini dapat dilakukan berulang, masing-masing dalam tempo 20 menit dan sebaiknya dilakukan pada ruangan khusus.

3. Melalui Biofeedback

Dilakukan melalui bimbingan medis, seperti : dokter, psikiater atau psikolog, pada akhirnya karyawan diharapkan mampu menghilangkan stres yang sedang dialaminya.

4. Kesehatan pribadi

Merupakan tindakan pencegahan (preventif) kemungkinan terjadinya stress, yang dapat dilakukan sendiri oleh karyawan yang bersangkutan. Dianjurkan agar secara periodic dan continue karyawan memeriksakan kondisi kesehatannya. Selain itu perlu dibiasakan olah raga, makanan yang mengandung gizi dan istirahat yang cukup.

d. Cara Mengatasi Stres Kerja

Dalam mengatasi stress dapat dilakukan melalui beberapa pola, antara lain :

1. Sehat

Sehat merupakan pola menghadapi stres yang sangat baik. yaitu dengan tetap menjaga perilaku serta tindakan. Adanya stress tidak berdampak negative serta menimbulkan gangguan. Namun, justru terlatih dan menjadi sehat dan karyawan menjadi berkembang kompetensi dirinya. 


\section{Harmonis}

Harmonis, adalah pola bagaimana seorang karyawan dalam menghadapi stres dituntut memanage waktu dengan kegiatan secara harmonis, sehingga tidak menimbukan dampak negative dan hambatan. Pola ini menuntut karyawan dapat mengelola waktunya dengan baik.

3. Patologis

Pola ini menuntut karyawan dalam menghadapi stres yang tidak berdampak terhadap gangguan secara fisik maupun psikologis.

e. Indikator Stres Kerja

Berdasarkan indikator-indikator stres kerja menurut Mangkunegara (2015:157) sebagai berikut :

1. Beban kerja adalah salah satu faktor yang dapat menmbulkan stress kerja karyawan

2. Waktu kerja adalah waktu yang dialami oleh karyawan terkadang dikejar waktu, semua pekerjaan yang ada di perusahaan itu adalah pesanan dari para konsumen sehingga waktu yang dibutuhkan sangat sedikit untuk membuat satu macam pekerja pihak perusahaan sudah menghitung seberapa lama waktu yang dipakai untuk satu unit pekerjaan.

3. Konflik kerja adalah konflik yang muncul dipicu akibat komunikasi yang kurang baik, hubungan antar individu atau divisi di dalam organisasi perusahaan.

4. Lingkungan kerja merupakan satu faktor yang mendukung suatu kinerja karyawan.

5. Jenjang karir adalah karyawan mempunyai hak untuk naik jabatan jengjang karir dalam perusahaan yang jelas. 


\section{Kinerja}

1. Pengertian kinerja

Kinerja berasal dari istilah kata job performance, yang merupakan hasil/prestasi kerja seseorang dalam memikul tanggungjawab pekerjaannya. Indikator kinerja secara umum dapat dilihat dari cara bagaimana karyawan yang bersangkutan dalam menyelesaikan tugas dan tanggungjawabnya, baik dari segi kualitas maupun kuantitasnya selama periode tertentu.

Pendapat Sutrisno (2015:172) “Kinerja karyawan adalah hasil kerja karyawan dilihat dari aspek kualitas, kuantitas, waktu kerja, dan kerja sama untuk mencapai tujuan yang sudah ditetapkan organisasi."

Sedangkan menurut pendapat Wibowo (2016:2) “ kinerja mempunyai makna lebih luas, bukan hanya menyatakan sebagai hasil kerja, tetapi bagaimana proses kerja berlangsung. Kinerja adalah tentang melakukan pekerjaan dan hasil yang dicapai dari pekerjaan tersebut. Kinerja adalah tentang apa yang dikerjakan dan bagaimana mengerjakannya."

\section{Faktor pengaruh kinerja}

Ada 2 (dua) faktor yang dapat mempengaruhi kinerja. Yaitu factor : ability (kemampuan) dan motivation (motivasi). Hal ini sesuai dengan pendapat keoth davis (1964) dalam A.A. Anwar Prabu Mangkunegara (2013: 67)

a. Ability (kemampuan)

Secara psikologis, ability (kemampuan) karyawan terdiri dari kemampuan yang didasarkan atas kecerdasan intelektual (IQ) dan pengetahuan/ ketrampilan (knowledge/skill). Karyawan apabila memiliki IQ dengan diatas rata-rata (antara IQ 110 sampai dengan 120) di dukung latar belakang pendidikan yang memadai pada posisi jabatanya dan terampil dalam menjalankan tugasnya, maka 
lebih mudah untuk mencapai hasil yang optimal sesuai yang diharapkan. Oleh karena itu, prinsip yang perlu diperhatiakn perusahaan dalam menentukan karyawannya menggunakan konsep "the right man in the right place, the right man on the right job" (orang yang tepat di tempat yang tepat, orang yang tepat di pekerjaan yang tepat)

b. Motivation (motivasi)

Motivasi merupakan dorongan yang ditimbulkan dari dalam diri seorang karyawan untuk dapat menghadapi dan menyelesaikan berbagai masalah yang dihadapinya dalam menjalankan tugastugasnya sebagai karyawan di dalam perusahaannya. Motivasi yang tinggi pada seorang karyawan dalam bekerja akan berkontribusi tercapainya tujuan perusahaan.

\section{Tujuan Penilaian/Evaluasi Kerja}

Tujuan evaluasi kerja adalah untuk mengetahui dan mengevaluasi konerja seseorang terhadap tugas dan tanggungjawabnya. Tujuan dari evaluasi kinerja menurut Agus Suryoto (1999) dalam Dr. A.A. Anwar Prabu Mangkunegara (2014: 10) sebagai berikut:

1. Meningkatkan saling pengertian antara karyawan tentang persyaratan kinerja.

2. Mencatat dan mengetahui hasil kerja karyawan karyawan, sehingga mereka termotivasi untuk membuat yang lebih baik, atau sekurang-kurangnya berprestasi sama dengan prestasi yang terdahulu.

3. Memberikan peluang kepada karyawan untuk mendiskusikan keinginan dan aspirasinya dan meningkatkan kepedulian terhadap karir atauterhadap pekerjaan yang diembannya sekarang. 
4. Indikator kinerja

Berdasarkan indikator-indikator kinerja menurut Mangkunegara (2015:76) sebagai berikut :

1. Kualitas kerja adalah suatu hasil yang bisar diukur dari tingkat efisiensi dan efektifitas seorang karyawan dalam melakukan suatu pekerjaan yang didukung oleh sumber daya lainnya dalam mencapai tujuan perusahaan secara umum

2. Kuantitas Kerja adalah jumlah kerja yang dilaksanakan oleh seseorang pegawai atau karyawan dalam suatu periode tertentu.

3. Tanggung Jawab merupakan kesadaran yang timbul dari dalam diri seseorang terhadap tingkah laku dan perbuatannya.

4. Kerjasama merupakan sinergi antar individu atau kelompok yang dilakukan secara bersama-sama untuk menyelesaikan pekerjaan lebih ringan.

5. Inisiatif merupakan kemampuan yang timbul akibat kesadaran yang tinggi dari dalam diri seseorang untuk melakukan atau menyelesaikan sesuatu pekerjaan, tanpa harus menunggu perintah dari atasan. 


\section{BAB IV \\ MOTIVASI DAN KINERJA KARYAWAN DI PT. XY}

\section{A. Profil PT. XY}

Sebelum menjadi PT dan Toko Online Muslim yang terkenal, dulunya PT. XY merupakan sebuah Toko obat-obatan herbal yang pelanggannya sudah cukup banyak. Masih berupa toko kecil dengan beberapa karyawan saja. Namun pemilik toko merasa bahwa toko obatnya kurang memiliki masa depan yang cerah, Akhirnya di tahun 2012 pemilik toko obat-obatan tersebut banting setir menjadi penjual baju dari rumahkerumah. Pemilik menjajakan bajunya dari pintu ke pintu, tak berselang lama pemilik memiliki inisiatif untuk berjualan melalui sosial media dari facebook dan website. Semakin hari pelanggan semakin banyak, tentu owner kewalahan dalam menjajakan produknya.

Sejak dahulu sampai sekarang, toko online ini selalu berkomitmen mengedepankan kenyamanan para customernya dalam belanja online, sehingga moto yang diusung adalah 'Happiness Is Yours'. Benar, kebahagiaan adalah milik Kamu! Kebahagiaan milik para customer, agen, reseller, supplier, karyawan, menejemen dan semua orang yang terlibat dengan MuslimGaleri.co.id. Membawa kebahagiaan untuk semua adalah prestasibagi MuslimGaleri.co.id

PT. XY senantiasa memperbaiki dan meningkatkan bentuk pelayanannya, serta selalu siap untuk menyajikan website yang 'user friendly'. Semua produk yang ditampilkan di website stoknya tersedia, semua produk sudah diberi deskripsi di dalamnya, produk yang dijual pun sudah melewati proses review oleh tim pengadaan barang. Sehingga berhak mendapatkan produkterbaik. 
PT. XY sangat 'concern' di semua tahap proses belanja online. Dimulai dari foto yang ditampilkan, fasilitas belanja online mandiri, pelayanan CS, proses packing, hingga proses pengantaran sampai dengan paket diterima oleh customer.

a. Visi dan Misi Perusahaan

1. Visi:

Menjadi Toko Online Busana Muslim Terbaik Di Dunia dalam hal pelayanan dan manfaatnya bagi orang banyak.

2. Misi:

a) Menjadi role model toko online di Indonesia.

b) Memberikan pengalaman belanja online terbaik bagi para customer.

c) Memberikan fasilitas dan juga pembinaan terbaik bagi para agen atau reseller.

d) Menciptakan SDM muslimgaleri.co.id yang bermutu, baik dari akhlak maupun kemampuan teknisnya

e) Mensejahteraan semua karyawan muslimgaleri.co.id dan lingkungan sekitar

b. Tujuan

1. Ingin mempermudah bagi siapa saja yang ingin berbelanja pakaian (baju) tanpa harus repot-repot keluar rumah

2. Menjadi toko online yang selalu di percaya para pelanggan

3. Memberikan produk dengan berbagai macam merk dengan harga yang bersaing

4. Memberikan produk dengan kualitas tinggi namun dengan harga yang terjangkau

5. Menjadi toko online yang selalu memberikan kepuasan bagi pelanggan dengan menjamin keaslian barang yang di beli, serta pengiriman yang relatif aman dan cepat.

c. Struktur Organisasi Perusahaan

Struktur organisasi merupakan kerangka pembagian tugas kepada unit-unit yang dibentuk untuk melaksanakan kegiatan-kegiatan pokok perusahaan, dengan adanya 
pembagian atas pemutusan tugas yang diberikan tersebut, dapat mencegah atau mendeteksi dengan cepat atas kesalahan-kesalahan dalam melaksanakan tugas yang telah diberikan perusahaan.

Pt. XY adalah sebuah perusahaan yang bergerak dibidang perdagangan, sudah memiliki pengalaman kurang lebih selama 9 tahun yang membuat website www.muslimgaleri.co.iduntuk penghubung antara pelanggan dan customer service. Karena memang disini menawarkan berbagai macam busana muslim dan aksesorisnya secara online tapi tetap terpercaya. Adapun keunggulan dari Muslim Galeri ini kami menawarkan produk dengan brand sendiri yang diproduksi sendiri dengan bahan yang berkualitas dan harga terjangkau.

Dibawah ini merupakan uaraian struktur organisasi dan tugas, wewenang dan tanggung jawab yang berlaku diperusahaan. Semua tugas, wewenang dan tanggung jawab yang berada dalam perusahaan dilakukan setiap hari demi untuk meningkatkan kinerja karyawan pada perusahaan tersebut dalam struktur organisasi ini kita dapat meninjau seperti apa struktur yang ada di dalam perusahaan.

\section{Struktur Organisasi}

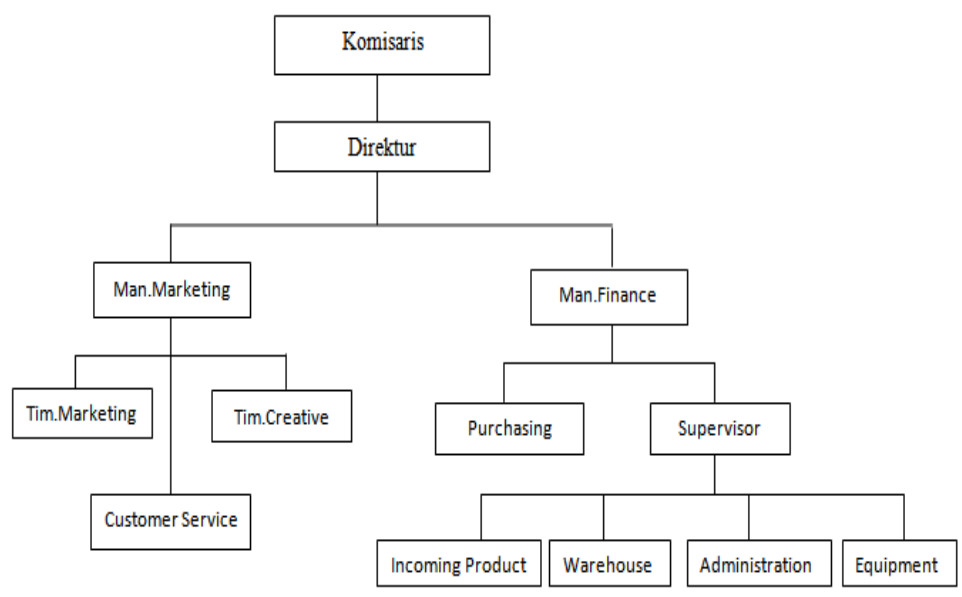


d. Uraian Pekerjaan

1. Komisaris

Melakukan pengawasan kegiatan pada suatu perusahaan atau organisasi serta memberi nasihat keapada Direksi. Serta yang bertanggung jawab mengawasi atas kelancaran serta kesehatan keuangan perusahaan.

2. Direktur

Sebagai koordinator, komunikator, pengambil keputusan, pemimpin, pengelola dan eksekutor dalam menjalankan dan memimpin perusahaan Manager.

3. Manajer Marketing

Mengambil keputusan yang berkaitan dengan pembelanjaan, merencanakan, mengatur dan mengontrol perencanaan, laporan dan pembiayaan perusahaan.

4. Tim Marketing

Seorang marketing mempunyai tugas untuk memastikan bahwa produk/jasa yang ditawarkan bisa menembus target pasar serta diterima dan disukai oleh pembeli yang akan terus kembali membeli dan menjadi pelanggan setia. Jadi, tugas seorang marketing sebenarnya mencakup seluruh proses dari hulu hingga hilir.

5. Tim Creative

Kerja yang dilakukan oleh orang-orang yang memiliki kreativitas di departemen kreatif.Semua iklan yang dibuat dari iklan cetak atau digital, iklan siaran, surat langsung, situs Web dan produk kampanye atau jasa semua lahir dari ide-ide kreatif oleh tim kreatif.

6. Tim Customer Service

Tugas customer service adalah membina relationship dengan customer dan menyampaikan keinginan customer ke bagian lain di dalam perusahaan. Tujuannya adalah agar perusahaan dapat memberikan pelayanan 
yang sesuai denngan kebutuhan dan keinginan customer.

7. Manajer Finance

Sebagai pengelolaan keuangan yang baik,merencanakan, mengembangkan, dan mengendalikan fungsi keuangan dan akuntansi di perusahaan.

8. Purchasing

Bagian yang mempunyai tugas dan wewenang untuk menyediakan material untuk keperluan produksi.

9. Supervisor

Menyelesaikan masalah sebisanya tanpa harus ditangani oleh atasan atau manager. Lalu sebagai penghubung antara Staf dan Manager.

10. Incoming Product

Mengendalikan kualitas atau mutu serta menguji produk sesuai dengan standar kualitas perusahaan.

11. Warehouse

Melengkapi pengiriman dan penyimpanan barang melalui pengolahan dan perintah pemuatan. Serta bertanggung jawab atas kebersihan dan kerapian di dalam area gudang barang

12. Administration

Tanggung jawab admin sangat luas namun intinya memastikan segala kegiatan yang bersifat administratif atau ketatausahaan kantor atau perusahaan berjalan dengan baik dan lancar.

13. Equipment

Equipment management bermanfaat untuk mencapai empat target bisnis yang penting bagi perusahaan:mengidentifikasikan masalah yang sebenarnya, memprioritaskan dan melancarkan tugas, menyediakan data yang mendukung pengelolaan pengeluaran langsung seperti biaya operasional,fungsi memberitahukan, di mana ada dan bagaimana cara mengatasi waktu luang untuk mengurangi biaya pengeluaran. 


\section{B. Karakteristik Karyawan}

1. Karakteristik

Objek dalam kajian ini adalah karyawan PT. XY dan sampel yang ditarik berjumlah 67 orang berdasarkan perhitungan jumlah populasi, penulis memilih menggunakan teknik pemilihan sampel yaitu sampel jenuh, diamana semua populasi dilibatkan.

2. Data karyawan berdasarkan jenis kelamin.

Dalam tabel ini dijelaskan bahwa sumber data atau karyawan yang diambil dalam kajian terdiri dari dua jenis kelamin yaitu laki-laki dan perempuan yang semuanya bekerja di PT. XY.

Tabel 4.1

Jenis Kelamin

\begin{tabular}{|c|c|c|c|}
\hline No & Jenis kelamin & Jumlah & Persentase (\%) \\
\hline 1 & Laki-laki & 24 & $35 \%$ \\
\hline 2 & Perempuan & 43 & $65 \%$ \\
\hline & Jumlah & 67 & $100 \%$ \\
\hline
\end{tabular}

Sumber : Data primer yang diolah

Berdasarkan hasil data responden yang diterima, disini terlihat bahwa perempuan lebih mendominasi dari pada laki-laki, hal imi terlihat dengan angka presentase laki-laki 24 responden yang berarti $35 \%$ dan perempuan 43 responden yang berarti $65 \%$.

3. Data responden berdasarkan usia responden

Responden menurut tingkat usia pada kajian ini terbagi menjadi 3 kategori. Adapun kategori ini dapat peulis gambarkan pada tabel dibawah ini : 


\section{Tabel 4.2}

\section{Usia Responden}

\begin{tabular}{|c|c|c|c|}
\hline No & Usia & Jumlah & Persentase \% \\
\hline 1 & $21-30$ & 54 & $80 \%$ \\
\hline 2 & $31-40$ & 10 & $15 \%$ \\
\hline 3 & $41-50$ & 3 & $5 \%$ \\
\hline & Jumlah & 67 & $100 \%$ \\
\hline
\end{tabular}

Sumber : Data primer yang diolah,

Dari hasil data responden yang diterima berdasarkan usia responden, terlihat bahwa responden yang berusia 21-30 tahun berjumlah 54 orang atau sebesar $80 \%$, responden yang berusia 31-40 tahun berjumlah 10 orang atau sebesar $15 \%$, responden yang berusia 41-50 tahun berjumlah 3 orang atau sebesar $5 \%$.

4. Data responden berdasarkan masa kerja

Lama kerja responden dapat penulis gambarkan pada tabel dibawah ini :

\section{Tabel 4.3}

Masa kerja

\begin{tabular}{|c|c|c|c|}
\hline No & Lama kerja & Jumlah & Presentase \% \\
\hline 1 & $1-3$ tahun & 55 & $82 \%$ \\
\hline 2 & $4-8$ tahun & 7 & $10 \%$ \\
\hline 3 & $9-15$ tahun & 5 & $8 \%$ \\
\hline & Jumlah & 67 & $100 \%$ \\
\hline
\end{tabular}

Sumber : Data primer yang diolah,

Berdasarkan hasil data yang diterima, terlihat bahwa karyawan yang bekerja 1-3 tahun berjumlah 55 orang atau $82 \%$ responden, karyawan yang bekerja $4-8$ tahun berjumlah 7 orang atau $10 \%$ responden, dan karyawan yang bekerja selama 9-15 tahun berjumlah 5 orang atau $8 \%$ responden. 
5. Data Responden Berdasarkan Tingkat pendidikan

Dalam pengisian kuesioner responden mempunyai latar pendidikan yang tidak sama, maka tabel ini akan menjelaskan tingkatan-tingkatan pendidikan responden, berikut ini penjelasannya:

\section{Tabel 4.4}

\section{Pendidikan}

\begin{tabular}{|c|c|c|c|}
\hline No & Pendidikan & Jumlah & Presentase \% \\
\hline 1 & SMP & 4 & $5 \%$ \\
\hline 2 & SMA & 47 & $70 \%$ \\
\hline 3 & D3 & 4 & $5 \%$ \\
\hline 4 & S1 & 12 & $15 \%$ \\
\hline & Jumlah & 67 & $100 \%$ \\
\hline
\end{tabular}

Sumber : Data yang diolah

Berdasarkan pada 3.4. dapat kita lihat karyawan tingkat pendidikan SMP berjumlah 4 orang atau 5\%, tingkat pendidikan SMA berjumlah 47 orang atau $70 \%$, tingkat pendidikan D3 berjumlah 4 orang atau 5\%, tingkat pendidikan S1 berjumlah 12 orang atau 15\%.

6. Data responden berdasarkan Status

Responden menurut status kajian ini dibagi menjadi 2 (dua) kategori. Adapun kedua kategori ini dapat penulis gambarkan pada tabel dibawah ini :

\section{Tabel 4.5}

Status

\begin{tabular}{|c|c|c|c|}
\hline No & Status & Jumlah & Presentase \% \\
\hline 1 & Belum kawin & 37 & $55 \%$ \\
\hline 2 & Kawin & 30 & $45 \%$ \\
\hline & Jumlah & 67 & $100 \%$ \\
\hline
\end{tabular}

Sumber : Data primer yang diolah,

Berdasarkan hasil data responden yang diterima, disini terlihat bahwa status belum kawin lebih mendominasi dari pada kawin, hal ini terlihat dengan angka presentase belum kawin sebanyak 37 orang 
responden atau 55\%, dan yang kawin sebanyak 30 orang responden atau $45 \%$.

7. Data kajian

Kajian ini dilakukan dengan cara penyebaran kuisioner kepada 67 responden dari karyawan pada CV. Muslim Galeri Indonesia sebagai sampel dengan skor yang diberikan sebagai berikut :

a. Analisis Deskriptif Variabel Motivasi (X1)

Di bawah ini merupakan hasil rekapitulasi jawaban responden :

\section{Tabel 4.6}

\section{Penilaian Responden pada Variabel Motivasi (X1)}

\begin{tabular}{|c|c|c|c|c|c|c|c|c|c|c|}
\hline \multirow[t]{2}{*}{ No } & Pernyataan & \multicolumn{5}{|c|}{ Tanggapan } & \multirow[t]{2}{*}{ Total } & \multirow[t]{2}{*}{ Skor } & \multirow[t]{2}{*}{ Mean } & \multirow[t]{2}{*}{ Ket } \\
\hline & Kebutuhan fisiologi & SS & $\mathrm{S}$ & CS & TS & STS & & & & \\
\hline 1 & $\begin{array}{c}\text { Gaji yang diterima } \\
\text { dirasakan sudah dapat } \\
\text { memenuhi kebutuhan } \\
\text { hidup karyawan dan } \\
\text { keluarga. }\end{array}$ & 13 & 28 & 21 & 5 & 0 & 67 & 250 & 3,73 & Baik \\
\hline \multirow[t]{3}{*}{2} & $\begin{array}{c}\text { Bonus yang saya } \\
\text { terima sebanding } \\
\text { dengan apa yang saya } \\
\text { kerjakan }\end{array}$ & 13 & 32 & 19 & 3 & 0 & 67 & 256 & 3,82 & Baik \\
\hline & & \multicolumn{7}{|c|}{ Rata-Rata Skor } & 3,77 & Baik \\
\hline & Kebutuan rasa aman & SS & $\mathrm{S}$ & $\mathrm{CS}$ & TS & STS & & & & \\
\hline 3 & $\begin{array}{l}\text { Kondisi dan lingkungan } \\
\text { kerja yang ada } \\
\text { dirasakan sudah aman }\end{array}$ & 18 & 30 & 17 & 2 & 0 & 67 & 265 & 3,95 & Baik \\
\hline \multirow[t]{3}{*}{4} & $\begin{array}{c}\text { Seluruh Karyawan } \\
\text { mendapatkan berbagai } \\
\text { tunjangan kesehatan } \\
\text { tanpa terkecuali }\end{array}$ & 4 & 27 & 32 & 4 & 0 & 67 & 232 & 3,46 & Baik \\
\hline & & \multicolumn{7}{|c|}{ Rata-Rata Skor } & 3.70 & Baik \\
\hline & Kebutuhan Sosial & SS & $\mathrm{S}$ & $\mathrm{CS}$ & TS & STS & & & & \\
\hline 5 & $\begin{array}{l}\text { Hubungan komunikasi } \\
\text { antar karyawan saat ini } \\
\text { terjalin dengan baik. }\end{array}$ & 7 & 28 & 29 & 3 & 0 & 67 & 240 & 3,58 & Baik \\
\hline \multirow[t]{3}{*}{6} & $\begin{array}{c}\text { Antar karyawan saling } \\
\text { membantu dan bekerja } \\
\text { sama dalam penyelesaian } \\
\text { pekerjaan. }\end{array}$ & 7 & 18 & 29 & 13 & 0 & 67 & 220 & 3.28 & $\begin{array}{l}\text { Cukup } \\
\text { Baik }\end{array}$ \\
\hline & & \multicolumn{7}{|c|}{ Rata-Rata Skor } & 3.43 & Baik \\
\hline & Kebutuhan Penghargaan & SS & S & $\mathrm{CS}$ & TS & STS & & & & \\
\hline
\end{tabular}




\begin{tabular}{|c|c|c|c|c|c|c|c|c|c|c|}
\hline 7 & $\begin{array}{c}\text { Karyawan yang } \\
\text { berprestasi selalu } \\
\text { mendapatkan } \\
\text { penghargaan dari } \\
\text { perusahaan }\end{array}$ & 2 & 32 & 25 & 8 & 0 & 67 & 229 & 3,41 & Baik \\
\hline \multirow[t]{3}{*}{8} & $\begin{array}{c}\text { Pimpinan saya } \\
\text { menghargai hasil kerja } \\
\text { saya. }\end{array}$ & 3 & 33 & 18 & 11 & 2 & 67 & 225 & 3,35 & $\begin{array}{c}\text { Cukup } \\
\text { Baik }\end{array}$ \\
\hline & & \multicolumn{7}{|c|}{ Rata-Rata Skor } & 3,38 & $\begin{array}{l}\text { Cukup } \\
\text { Baik }\end{array}$ \\
\hline & $\begin{array}{c}\text { Kebutuhan aktualisasi } \\
\text { diri }\end{array}$ & SS & $\mathbf{S}$ & CS & TS & STS & & & & \\
\hline 9 & $\begin{array}{c}\text { Karyawan bisa } \\
\text { mengeksplor } \\
\text { kemampuan atau potensi } \\
\text { yang dimiliki dalam } \\
\text { proses penyelesaian } \\
\text { kinerja. }\end{array}$ & 19 & 30 & 16 & 2 & 0 & 67 & 267 & 3,98 & Baik \\
\hline \multirow[t]{3}{*}{10} & $\begin{array}{l}\text { Karyawan sangat aktif } \\
\text { dalam menyuarakan } \\
\text { pendapat dan keluhan }\end{array}$ & 3 & 29 & 31 & 4 & 0 & 67 & 232 & 3,46 & Baik \\
\hline & \multicolumn{8}{|c|}{ Rata-Rata Skor } & 3,72 & Baik \\
\hline & \multicolumn{8}{|c|}{ Mean Skor } & 3.60 & Baik \\
\hline
\end{tabular}

Sumber : Data primer hasil olahan kuisioner

Berdasarkan distribusi jawaban kuesioner diatas, maka analisis tanggapan responden terhadap item-item pernyataan variabel Motivasi sebagai berikut :

1.Tanggapan responden terhadap pernyataan No. 1, yaitu "Gaji yang diterima dirasakan sudah dapat memenuhi kebutuhan hidup karyawan dan keluarga", mendapat skala interval 3,73 kategori Baik dimana terdapat 13 responden menjawab "Sangat Setuju", 28 responden menjawab "Setuju" dan 21 responden menjawab "Cukup Setuju". Hal ini menunjukan bahwa Gaji yang diterima dirasakan sudah cukup oleh karyawan walaupun masih ada beberapa karyawan yang merasakan gaji tersebut belum cukup.

2.Tanggapan responden terhadap pernyataan No. 2 yaitu "Bonus yang saya terima sebanding dengan apa yang saya kerjakan", mendapat skala interval 3,82 kategori Baik dimana terdapat 13 responden menjawab "Sangat Setuju", 32 responden menjawab "Setuju" dan 19 responden menjawab "Cukup setuju". Hal ini menunjukan bahwa bonus yang diterima dirasakan sudah cukup oleh karyawan walaupun masih ada beberapa 
karyawan yang merasakan bonus tersebut belum cukup.

3.Tanggapan responden terhadap pernyataan No. 3 yaitu "Kondisi dan lingkungan kerja yang ada dirasakan sudah aman", mendapat skala interval 3,95 kategori Baik dimana terdapat 18 responden menjawab "Sangat Setuju", 30 responden menjawab "Setuju" dan 17 responden menjawab "Cukup setuju". Hal ini menunjukan lingkungan kerja dirasakan sudah cukup aman oleh karyawan walaupun masih ada beberapa karyawan yang merasakan lingkungan masih belum aman.

4.Tanggapan responden terhadap pernyataan No. 4 yaitu "Seluruh karyawan mendapatkan berbagai tunjangan kesehatan tanpa terkecuali", mendapat skala interval 3,46 kategori Baik dimana terdapat 4 responden menjawab "Sangat Setuju", 27 responden menjawab "Setuju" dan 32 responden menjawab "Cukup setuju". Hal ini menunjukan tunjangan kesehatan dirasakan sudah cukup merata diterima oleh karyawan walaupun masih ada beberapa karyawan yang merasa tidak merasakan manfaat tunjangan kesehatan tersebut.

5.Tanggapan responden terhadap pernyataan No. 5 yaitu "Hubungan komunikasi antar karyawan saat ini terjalin dengan baik", mendapat skala interval 3,58 kategori Baik dimana terdapat 7 responden menjawab "Sangat Setuju", 28 responden menjawab "Setuju" dan 29 responden menjawab "Cukup setuju". Hal ini menunjukan hubungan komunikasi antar karyawan terjalin dengan baik meskipun ada beberapa yang tidak sejalan. 
6.Tanggapan responden terhadap pernyataan No. 6 yaitu "Antar karyawan saling membantu dan bekerja sama dalam penyelesaian pekerjaan", mendapat skala interval 3,28 kategori Cukup Baik dimana terdapat 7 responden menjawab "Sangat Setuju", 18 responden menjawab "Setuju" dan 29 responden menjawab "Cukup setuju". Hal ini menunjukan sikap saling tolong menolong antar karyawan terjalin dengan cukup baik, meskipun ada beberapa yang tidak setuju dengan hal tersebut.

7.Tanggapan responden terhadap pernyataan No. 7 yaitu "Karyawan yang berprestasi selalu mendapatkan penghargaan dari perusahaan", mendapat skala interval 3,41 kategori Baik dimana terdapat 2 responden menjawab "Sangat Setuju", 32 responden menjawab "Setuju" dan 25 responden menjawab "Cukup setuju". Hal ini menunjukan penghargaan yang diberikan perusahaan kepada karyawan sudah baik namun, ada beberapa yang kurang setuju dengan hal pernyataan tersebut.

8.Tanggapan responden terhadap pernyataan No. 8 yaitu "Pimpinan saya menghargai hasil kerja saya", mendapat skala interval 3,35 kategori Cukup Baik dimana terdapat 3 responden menjawab "Sangat Setuju", 33 responden menjawab "Setuju" dan 18 responden menjawab "Cukup setuju". Hal ini menunjukan pimpinan cukup mengahargai kinerja karyawan, namun ada sebagian karyawan yang tidak merasakan hal demikian.

9.Tanggapan responden terhadap pernyataan No. 9 yaitu "Karyawan bisa mengeksplor kemampuan atau potensi yang dimiliki dalam proses penyelesaian kinerja", mendapat skala interval 
3,98 kategori Baik dimana terdapat 19 responden menjawab "Sangat Setuju", 3 responden menjawab "Setuju" dan 16 responden menjawab "Cukup setuju". Hal ini menunjukan karyawan mampu mengeksplor kemampuanya dengan baik, meskipun ada sebagian yang belum bisa mengseksplor kemampuan dengan baik.

10. Tanggapan responden terhadap pernyataan No. 10 yaitu "Karyawan sangat aktif dalam menyuarakan pendapat dan keluhan", mendapat skala interval 3,46 kategori Baik dimana terdapat 3 responden menjawab "Sangat Setuju", 2 responden menjawab "Setuju" dan 31 responden menjawab "Cukup setuju". Hal ini menunjukan bahwa karyawan cukup mampu dalam menyuarakan pendapat dengan baik.

11. Dari hasil di atas dapat disimpulkan bahwa motivasi pada PT. XY berdasarkan 67 responden dari 10 butri Pernyataaan dengan nilai rata-rata skor sebesar 3.60 dikategorikan Baik dan hasil tertinggi pada pernyataan 1 dan dan 2 sebesar 3,77 dan terendah di pernyataan 7 dan 8 sebanyak 3,38 .

b. Analisis Asosiatif Variabel Stres Kerja (X2)

Dari hasil jawaban responden terhadap pengaruh stres kerja dipoeroleh melalui kuisioner yang jawaban tersebut kemudian akan dianalisis oleh penulis dengan menggunakan presentase jawaban yang tertuang dan dijelaskan dalam tabel sebagai berikut : 
Tabel 4.7

Penilaian Responden pada Variabel Stres Kerja(X2)

\begin{tabular}{|c|c|c|c|c|c|c|c|c|c|c|}
\hline \multirow[t]{2}{*}{ No } & Pernyataan & \multicolumn{5}{|c|}{ Tanggapan } & \multirow[t]{2}{*}{ Total } & \multirow[t]{2}{*}{ Skor } & \multirow[t]{2}{*}{ Mean } & \multirow[t]{2}{*}{ Ket } \\
\hline & Beban kerja & SS & $\mathrm{S}$ & CS & TS & STS & & & & \\
\hline 1 & $\begin{array}{c}\text { Beban kerja yang } \\
\text { diberikan sesuai dengan } \\
\text { kemampuan saya }\end{array}$ & 9 & 39 & 18 & 1 & 0 & 67 & 257 & 3,83 & Baik \\
\hline \multirow[t]{3}{*}{2} & $\begin{array}{c}\text { Setiap tugas yang } \\
\text { diberikan dirasakan } \\
\text { bukan sebagai beban bagi } \\
\text { karyawan }\end{array}$ & 14 & 17 & 24 & 12 & 0 & 67 & 234 & 3,49 & Baik \\
\hline & & \multicolumn{7}{|c|}{ Rata-Rata Skor } & 3,66 & Baik \\
\hline & Waktu kerja & SS & $\mathrm{S}$ & CS & TS & STS & & & & \\
\hline 3 & $\begin{array}{l}\text { Waktu kerja yang } \\
\text { diberikan perusahaan } \\
\text { sesuai dengan standar } \\
\text { kerja yang ditetapkan } \\
\text { pemerintah. }\end{array}$ & 3 & 24 & 31 & 9 & 0 & 67 & 222 & 3,31 & $\begin{array}{c}\text { Cukup } \\
\text { Baik }\end{array}$ \\
\hline \multirow[t]{3}{*}{4} & $\begin{array}{l}\text { Karyawan menerima } \\
\text { dengan baik setiap tugas } \\
\text { tambahan yang diberikan }\end{array}$ & 13 & 29 & 23 & 2 & 0 & 67 & 254 & 3,71 & Baik \\
\hline & & \multicolumn{7}{|c|}{ Rata-Rata Skor } & 3,51 & Baik \\
\hline & Konflik kerja & SS & $\mathrm{S}$ & CS & TS & STS & & & & \\
\hline 5 & $\begin{array}{c}\text { Karyawan bersikap yang } \\
\text { selalu baik terhadap } \\
\text { pembeli. }\end{array}$ & 5 & 29 & 27 & 6 & 0 & 67 & 261 & 3,89 & Baik \\
\hline \multirow[t]{3}{*}{6} & $\begin{array}{l}\text { Karyawan dan customer } \\
\text { menjalin hubungan baik. }\end{array}$ & 15 & 24 & 25 & 3 & 0 & 67 & 252 & 3,76 & Baik \\
\hline & & \multicolumn{7}{|c|}{ Rata-Rata Skor } & 3,82 & Baik \\
\hline & Lingkungan kerja & SS & $\mathrm{S}$ & CS & TS & STS & & & & \\
\hline 7 & $\begin{array}{l}\text { Lingkungan kerja yang } \\
\text { saya tempati sudah } \\
\text { nyaman dan kondusif } \\
\text { untuk bekerja. }\end{array}$ & 9 & 39 & 18 & 1 & 0 & 67 & 257 & 3,83 & Baik \\
\hline
\end{tabular}

\begin{tabular}{|c|c|c|c|c|c|c|c|c|c|c|}
\hline 8 & $\begin{array}{l}\text { Kondisi kerja yang tenang } \\
\text { dapatmenambah tingkat } \\
\text { konsentrasi dalam } \\
\text { menvelessikan pekerjaan. }\end{array}$ & 14 & 17 & 24 & 12 & 0 & 67 & 234 & 3,49 & Baik \\
\hline & & \multicolumn{7}{|c|}{ Rata-Rata Skor } & 3,66 & Baik \\
\hline & Jenjang karir & SS & S & CS & IS & STS & & & & \\
\hline 9 & $\begin{array}{c}\text { Karyawan yang } \\
\text { kinerjanya baik akan } \\
\text { mendapatkan posisi yang } \\
\text { lebih baik. }\end{array}$ & 7 & 41 & 18 & 1 & 0 & 67 & 255 & 3,80 & Baik \\
\hline 10 & $\begin{array}{l}\text { Karyawan yang sudah } \\
\text { lama bekerja dapat } \\
\text { diangkatmenjadi } \\
\text { karyawan tetap. }\end{array}$ & 12 & 40 & 14 & 1 & 0 & 67 & 264 & 3,94 & Baik \\
\hline & \multicolumn{8}{|c|}{ Rata-Rata Skof } & 3.87 & Baik \\
\hline & \multicolumn{8}{|c|}{ Mean Skor } & 3,70 & Baik \\
\hline
\end{tabular}

Sumber : data primer hasil olahan kuisioner 
Berdasarkan distribusi jawaban kuesioner diatas, maka analisis tanggapan responden terhadap item-item pernyataan variabel Stress Kerja sebagai berikut :

1. Tanggapan responden terhadap pernyataan No. 1 yaitu "Beban kerja yang diberikan sesuai dengan kemampuan saya", mendapat skala interval 3,83 kategori Baik dimana terdapat 9 responden menjawab "Sangat Setuju", 39 responden menjawab "Setuju" dan 18 responden menjawab "Cukup setuju". Hal ini menunjukan bahwa karyawan mampu bekerja sesuai dengan kemampuannya.

2. Tanggapan responden terhadap pernyataan No. 2 yaitu "Setiap tugas yang diberikan dirasakan bukan sebagai beban bagi karyawan", mendapat skala interval 3,49 kategori Baik dimana terdapat 14 responden menjawab "Sangat Setuju", 17 responden menjawab "Setuju" dan 24 responden menjawab "Cukup setuju". Hal ini menunjukan bekerja cukup tidak ada beban.

3. Tanggapan responden terhadap pernyataan No. 3 yaitu "Waktu kerja yang diberikan perusahaan sesuai dengan standar kerja yang ditetapkan pemerintah", mendapat skala interval 3,33 kategori Cukup Baik dimana terdapat 3 responden menjawab "Sangat Setuju", 24 responden menjawab "Setuju" dan 31 responden menjawab "Cukup setuju". Hal ini menunjukan waktu kerja yang diberikan perusahaan cukup sesuai dengan peraturan pemerintah walaupun terkadang ada beberapa karyawan yang merasa jam kerjanya tidak sesuai. 
4. Tanggapan responden terhadap pernyataan No. 4 yaitu "Karyawan menerima dengan baik setiap tugas tambahan yang diberikan", mendapat skala interval 3,71 kategori Baik dimana terdapat 13 responden menjawab "Sangat Setuju", 29 responden menjawab "Setuju" dan 23 responden menjawab "Cukup setuju". Hal ini menunjukan bahwa karywan menerima dengan baik setiap tugas yang diberikan walaupun ada sebagian yang merasa berat dengan tugas yang diberikan.

5. Tanggapan responden terhadap pernyataan No. 5 yaitu "Karyawan selalu bersikap baik kepada pembeli", mendapat skala interval 3,89 kategori Baik dimana terdapat 5 responden menjawab "Sangat Setuju", 29 responden menjawab "Setuju" dan 27 responden menjawab "Cukup setuju". Hal ini menunjukan bahwa karyawan bersikap baik kepada konsumen.

6. Tanggapan responden terhadap pernyataan No. 6 yaitu "Karyawan dan customer menjalin hubungan baik", mendapat skala interval 3,76 kategori Baik dimana terdapat 15 responden menjawab "Sangat Setuju", 24 responden menjawab "Setuju" dan 25 responden menjawab "Cukup setuju". Hal ini menunjukan bahwa karyawan dan konsumen menjalin hubungan dengan baik.

7. Tanggapan responden terhadap pernyataan No. 7 yaitu "Lingkungan kerja yang saya tempati sudah nyaman dan kondusif untuk bekerja", mendapat skala interval 3,83 kategori Baik dimana terdapat 9 responden menjawab "Sangat Setuju", 39 responden menjawab "Setuju" dan 18 responden menjawab "Cukup setuju". Hal ini 
menunjukan bahwa karyawan merasa nyaman dengan lingkungan kerja nya saat ini.

8. Tanggapan responden terhadap pernyataan No. 8 yaitu "Kondisi kerja yang tenang dapat menambah tingkat konsentrasi dalam menyelesaikan pekerjaan", mendapat skala interval 3,49 kategori Baik dimana terdapat 14 responden menjawab "Sangat Setuju", 17 responden menjawab "Setuju" dan 24 responden menjawab "Cukup setuju". Hal ini menunjukan bahwa karyawan bisa meningkatkan konsentrasi jika kondisi kerja tenang.

9. Tanggapan responden terhadap pernyataan No. 9 yaitu "Karyawan yang kinerjanya baik akan mendapatkan posisi yang lebih baik", mendapat skala interval 3,80 kategori Baik dimana terdapat 7 responden menjawab "Sangat Setuju", 41 responden menjawab "Setuju" dan 18 responden menjawab "Cukup setuju”. Karyawan setuju jika mereka memiliki kinerja yang baik maka akan mendapatkan posisi yang lebih baik.

10. Tanggapan responden terhadap pernyataan No. 10 yaitu "Karyawan yang sudah lama bekerja dapat diangkat menjadi karyawan tetap", mendapat skala interval 3,94 kategori Baik dimana terdapat 12 responden menjawab "Sangat Setuju", 40 responden menjawab "Setuju" dan 14 responden menjawab "Cukup setujuhal tersebut menunjukkan karyawan yang sudah lama bekerja bisa menjadi karyawan tetap.

Dari hasil di atas dapat disimpulkan bahwa motivasi pada CV. Muslim Galeri Indonesia berdasarkan 67 responden dari 10 butri Pernyataaan dengan nilai rata-rata skor sebesar 3,70 dikategorikan Baik dan hasil 
tertinggi pada pernyataaan 9 dan 10 sebesar 3,87 dan terendah di pernyataan 3 dan 4 sebanyak 3,51.

c. Analisis Asosiatif Variabel Kinerja $(Y)$

Dari hasil jawaban responden terhadap pengaruh stres kerja dipoeroleh melalui kuisioner yang jawaban tersebut kemudian akan dianalisis oleh penulis dengan menggunakan presentase jawaban yang tertuang dan dijelaskan dalam tabel sebagai berikut :

\section{Tabel 4.8}

Penilaian Responden pada Variabel Kinerja (Y)

\begin{tabular}{|c|c|c|c|c|c|c|c|c|c|c|}
\hline \multirow[t]{2}{*}{ No } & Pernyataan & \multicolumn{5}{|c|}{ Tanggapan } & \multirow[t]{2}{*}{ Total } & \multirow[t]{2}{*}{ Skor } & \multirow[t]{2}{*}{ Mean } & \multirow[t]{2}{*}{ Ket } \\
\hline & Kualitas Kerja & SS & $\mathrm{S}$ & CS & TS & STS & & & & \\
\hline 1 & $\begin{array}{l}\text { Karyawan menjalankan } \\
\text { pekerjaannya teliti, cermat } \\
\text { dan jarang membuat } \\
\text { kesalahan. }\end{array}$ & 14 & 18 & 23 & 12 & 0 & 67 & 235 & 3,50 & Baik \\
\hline \multirow[t]{3}{*}{2} & $\begin{array}{c}\text { Karyawan dalam } \\
\text { menjalankan pekerjaannya } \\
\text { mengikuti SOP yang } \\
\text { berlaku. }\end{array}$ & 5 & 32 & 11 & 18 & 0 & 67 & 222 & 3,31 & $\begin{array}{l}\text { Cukup } \\
\text { Baik }\end{array}$ \\
\hline & & \multicolumn{7}{|c|}{ Rata-Rata Skor } & 3,40 & Baik \\
\hline & Kuantitas Kerja & SS & $S$ & CS & TS & STS & & & & \\
\hline 3 & $\begin{array}{l}\text { Karyawan selalu tepat } \\
\text { waktu dalam } \\
\text { menyelesaikan pekerjaan. }\end{array}$ & 19 & 25 & 18 & 5 & 0 & 67 & 259 & 3,86 & Baik \\
\hline \multirow[t]{3}{*}{4} & $\begin{array}{l}\text { Jumlah karyawan yang ada } \\
\text { sekarang sesuai dengan } \\
\text { volume pekerjaan yang } \\
\text { ada. }\end{array}$ & 10 & 41 & 13 & 3 & 0 & 67 & 259 & 3,86 & Baik \\
\hline & & \multicolumn{7}{|c|}{ Rata-Rata Skor } & 3,86 & Baik \\
\hline & Tanggung Jawab & SS & $\mathrm{S}$ & CS & TS & STS & & & & \\
\hline 5 & $\begin{array}{l}\text { Karyawan memanfaatkan } \\
\text { waktu kerja dengan efektif } \\
\text { dan efisien dan tidak } \\
\text { dengan mengobrol, main } \\
\text { game, belanja online. }\end{array}$ & 20 & 36 & 11 & 0 & 0 & 67 & 277 & 4,13 & Baik \\
\hline \multirow[t]{3}{*}{6} & $\begin{array}{l}\text { Karyawan bersedia } \\
\text { menerima resiko atas } \\
\text { pekerjaan yang } \\
\text { dilakukannya }\end{array}$ & 13 & 32 & 19 & 3 & 0 & 67 & 256 & 3,82 & Baik \\
\hline & & \multicolumn{7}{|c|}{ Rata-Rata Skor } & 3,97 & Baik \\
\hline & Kerjasama & SS & $S$ & CS & TS & STS & & & & \\
\hline
\end{tabular}




\begin{tabular}{|c|c|c|c|c|c|c|c|c|c|c|c|}
\hline 7 & $\begin{array}{c}\text { Karyawan dapat bekerja } \\
\text { sama antar sesama } \\
\text { karyawan dalam } \\
\text { menyelesaikan } \\
\text { pekerjaannya. }\end{array}$ & 4 & 27 & 32 & & 0 & 0 & 67 & 197 & 2,94 & $\begin{array}{c}\text { Cukup } \\
\text { Baik }\end{array}$ \\
\hline \multirow[t]{3}{*}{8} & $\begin{array}{c}\text { Karyawan mampu } \\
\text { berkomunikasi baik } \\
\text { dengan rekan kerja lainnya }\end{array}$ & 13 & 32 & 17 & & 5 & 0 & 67 & 254 & 3,79 & Baik \\
\hline & & \multicolumn{8}{|c|}{ Rata-Rata Skor } & 3,36 & $\begin{array}{c}\text { Cukup } \\
\text { Baik }\end{array}$ \\
\hline & Inisiatif & SS & S & CS & TS & STS & & & & & \\
\hline 9 & $\begin{array}{c}\text { Karyawan berani } \\
\text { memberikan ide atau } \\
\text { gagasan kepada atasan. }\end{array}$ & 17 & 38 & 10 & 2 & 0 & 67 & & 273 & 4,07 & Baik \\
\hline \multirow[t]{3}{*}{10} & $\begin{array}{c}\text { Karyawan } \\
\text { dapat mengemukakan } \\
\text { pendapat dengan baik. }\end{array}$ & 14 & 39 & 13 & 1 & 0 & 67 & & 267 & 3,98 & Baik \\
\hline & \multicolumn{9}{|c|}{ Rata-Rata Skor } & 4.02 & Baik \\
\hline & & & & & & & & & & 3.72 & Baik \\
\hline
\end{tabular}

Sumber : data primer hasil olahan kuision

Berdasarkan distribusi jawaban kuesioner diatas, maka analisis tanggapan responden terhadap item-item pernyataan variabel Kinerja sebagai berikut:

1. Tanggapan responden terhadap pernyataan No. 1 yaitu "Karyawan menjalankan pekerjaannya teliti, cermat dan jarang membuat kesalahan", mendapat skala interval 3,50 kategori Baik dimana terdapat 14 responden menjawab "Sangat Setuju", 18 responden menjawab "Setuju" dan 23 responden menjawab "Cukup setuju". Hal ini menunjukan bahwa karyawan mampu bekerja dengan teliti meskipun ada sebagian karyawan yang kurang teliti dalam bekerja.

2. Tanggapan responden terhadap pernyataan No. 2 yaitu "Karyawan dalam menjalankan pekerjaannya mengikuti SOP", mendapat skala interval 3,31 kategori Cukup Baik dimana terdapat 5 responden menjawab "Sangat Setuju", 32 responden menjawab "Setuju" dan 11 responden menjawab "Cukup setuju". Hal ini menunjukan bahwa sebagian besar karyawan 
bekerja sesuai dengan SOP meskipun ada beberapa yang masih melanggar.

3. Tanggapan responden terhadap pernyataan No.

3 yaitu "Karyawan selalu tepat waktu dalam menyelesaikan pekerjaan", mendapat skala interval 3,86 kategori Baik dimana terdapat 19 responden menjawab "Sangat Setuju", 25 responden menjawab "Setuju" dan 18 responden menjawab "Cukup setuju". Hal ini menunjukan bahwa karyawan merasa tepat waktu dalam menyelesaikan pekerjaannya

4. Tanggapan responden terhadap pernyataan No. 4 yaitu "Jumlah karyawan yang ada sekarang sesuai dengan volume pekerjaan yang ada", mendapat skala interval 3,86 kategori Baik dimana terdapat 10 responden menjawab "Sangat Setuju", 41 responden menjawab "Setuju" dan 13 responden menjawab "Cukup setuju". Hal ini menunjukan volume pekerjaan sesuai dengan jumlah karyawan.

5. Tanggapan responden terhadap pernyataan No. 5 yaitu "Karyawan memanfaatkan waktu kerja dengan efektif dan efisien dan tidak dengan mengobrol, main game, dan belanja online", mendapat skala interval 4,13 kategori Baik dimana terdapat 20 responden menjawab "Sangat Setuju", 36 responden menjawab "Setuju" dan 11 responden menjawab "Cukup setuju". Hal ini menunjukan bahwa karyawan memanfaatkan waktu kerja dengan efektif dan efisien walopun tidak semua karyawan berbuat demikian.

6. Tanggapan responden terhadap pernyataan No. 6 yaitu "Karyawan bersedia menerima resiko atas pekerjaan yang dilakukannya", mendapat skala interval 3,82 kategori Baik dimana terdapat 
13 responden menjawab "Sangat Setuju", 32 responden menjawab "Setuju" dan 19 responden menjawab "Cukup setuju". Hal ini menunjukan bahwa karyawan berani tanggung jawab dengan apa yang dia kerjakan walaupun sebagian ada yang ragu-ragu dalam menjawab.

7. Tanggapan responden terhadap pernyataan No. 7 yaitu "Karyawan dapat bekerjasama antar sesama karyawan dalam menyelesaikan pekerjannya", mendapat skala interval 2,94 kategori Cukup Baik dimana terdapat 4 responden menjawab "Sangat Setuju", 27 responden menjawab "Setuju" dan 32 responden menjawab "Cukup setuju". Hal ini menunjukan bahwa karyawan cukup baik dalam menyelesaikan pekerjaan secara kerjasama.

8. Tanggapan responden terhadap pernyataan No. 8 yaitu "Karyawan mampu berkomunikasi baik dengan rekan kerja lainnya", mendapat skala interval 3,79 kategori Baik dimana terdapat 13 responden menjawab "Sangat Setuju", 32 responden menjawab "Setuju" dan 17 responden menjawab "Cukup setuju". Hal ini menunjukan bahwa karyawan mampu berkomunikasi baik dengan rekan kerja yang lainnya.

9. Tanggapan responden terhadap pernyataan No. 9 yaitu "Karyawan berani memberikan ide atau gagasan kepada atasan", mendapat skala interval 4,07 kategori Baik dimana terdapat 17 responden menjawab "Sangat Setuju", 38 responden menjawab "Setuju" dan 10 responden menjawab "Cukup setuju". Hal ini menunjukan aktif dalam memberikan ide dan gagasan walaupun ada sebagian yang pasif dalam hal ini. 
10. Tanggapan responden terhadap pernyataan No. 10 yaitu "Karyawan dapat mengemukakan pendapat dengan baik", mendapat skala interval 3,98 kategori Baik dimana terdapat 14 responden menjawab "Sangat Setuju", 39 responden menjawab "Setuju" dan 13 responden menjawab "Cukup setuju". Hal ini menunjukan bahwa karyawan berani mengemukakan pendapat dengan baik.

Dari hasil di atas dapat disimpulkan bahwa motivasi pada PT. XY berdasarkan 67 responden dari 10 butri Pernyataaan dengan nilai rata-rata skor sebesar 3.72 dikategorikan Baik dan hasil tertinggi pada pernyataaan 9 dan 10 sebesar 4.02 dan terendah di pernyataan 7 dan 8 sebanyak 3,36. 


\section{BAB V \\ PENUTUP}

Setelah bersama-sama membaca buku ini, diketahui bahwa Motivasi berpengaruh secara positif dan signifikan terhadap kinerja. Sedangkan stres kerja berpengaruh secara positif dan signifikan terhadap kinerja. Motivasi dan stres kerja secara serempak berpengaruh signifikan terhadap kinerja karyawan PT. XY. Berdasarkan kajian yang dikaji oleh penulis menunjukkan bahwa hubungan antar variabel motivasi dan stres kerja memiliki hubungan yang erat terhadap kinerja karyawan PT. XY.

Motivasi, pernyataan yang paling lemah adalah pernyataan mengenai Antar Karyawan saling membantu dan bekerja sama dalam penyelesaian pekerjaan dimana hanya mencapai score 3,28 dengan kategori cukup baik dalam kinerja namun lebih baik lagi jika karyawan lebih tenggang rasa atau memiliki rasa kepedulian antar sesama. Salah satu cara yang bisa dilakukan perusahaan adalah dengan mengadakan gathering, pelatihan teamwork sehingga timbul rasa kebersamaan diantara karyawan dan rasa kepedulian serta saling membantu antar karyawan.

Sedangkan Stres Kerja, pernyataan yang paling lemah adalah pernyataan mengenai Waktu yang diberikan perusahaan sesuai dengan standar kerja yang ditentukan dimana hanya mencapai skor 3,31 dengan kategori cukup baik. Dengan demikian perusahaan perlu memperhatikan hal tersebut, seperti menetapkan jam pulang kantor dengan sesuai. Atau memberi tambahan upah bagi karyawan yang kerja melebihi ketentuan yang ada. Selain itu perusahaan juga bisa mengadakan sesi sharing dimana karyawan bisa mengeluarkan uneg-unegnya dan dicari solusi bersama-sama.

Pada Kinerja, pernyataan yang paling lemah adalah pernyataan tentang Karyawan menjalankan pekerjaan mengikuti SOP yang berlaku dimana hanya mencapai skor 3,31. Ternyata fakta dilapangan, banyak sekali karyawan yang bekerja tidak sesuai dengan SOP. Dengan demikian perusahaan harus lebih 
tegas memberikan hukuman atau teguran bagi setiap karyawan yang bekerja dengan semaunya sendiri dengan mengabaikan SOP yang telah ada, tanpa ada pengecualian. 


\section{DAFTAR PUSTAKA}

Hasibuan, M. S.P. (2018). Manajmen Sumber Daya Manusia. Edisi Revisi, Jakarta: Bumi Aksara.

(2019). Manajmen Sumber Daya Manusia. Edisi Revisi, Jakarta: Bumi Aksara.

Mangkunegara \& Anwar, P. (2015). Manajemen Sumber Daya

Manusia dan Perusahaan. Bandung: PT. Remaja Rosdakarya.

(2014). Manajemen Sumber Daya Manusia dan Perusahaan. Bandung: PT. Remaja Rosdakarya.

(2015). Manajemen Sumber Daya Manusia dan Perusahaan. Bandung: PT. Remaja Rosdakarya.

(2016). Manajemen Sumber Daya Manusia dan Perusahaan. Bandung: PT. Remaja Rosdakarya.

Masrukhin. (2014). Statistik Deskriptif Bebasis Komputer. Kudus: Media Ilmu Press

Ridhotulloh, S \& Jauhar. (2015). Pengantar Manajemen. Jakarta: Prestasi Pustakarya.

Siagian, S.P. (2016). Manajemen Sumber Daya Manusia. Jakarta: Bumi Aksara

Sinambela, L.P. (2016). Manajemen Sumber Daya Manusia. Jakarta: Bumi Aksara.

Sugiyono. (2011). Metode Penelitian Pendidikan Pendekatan Kuantitatif, Kualitatif dan RED. Bandung: Alfabeta.

(2016). Metode Penelitian Administras. Bandung: Alfabeta. (2017). Metode Penelitian Kuantitatif, Kualitatif dan RED. Bandung: Alfabeta.

Sunyoto, D. (2015). Penelitian Sumber Daya Manusia. Yogyakarta: CAPS.

(2018). Penelitian Sumber Daya Manusia. Yogyakarta: CAPS.

Supomo, R \& Nurhayati, E. (2018). Manajemen Sumber Daya Manusia. Bandung: Yrama Widya. 
Sutrisno, E. (2015). Manajemen Sumber Daya Manusia. Jakarta: Kencana Prenadamedia Group.

Suwatno \& Priansa, D.J. (2016). Manajemen SDM dalam Organisasi Publik dan Bisnis. Bandung: Alfabeta

Rivai, V. (2014). Manajemen Sumber Daya Manusia. Jakarta: PT. Raja Grafindo Persada.

Wibowo. (2016). Manajemen Kinerja. Jakarta: PT. Raja Grafindo Persada.

Yani, M. (2012). Manajemen sumber daya manusia. Jakarta: Penerbit Mitra Wacana Media.

\section{Jurnal:}

Dewi, C, I, A, S \& Wibawa, I, M, A. (2016). Pengaruh Stres Kerja Dan Motivasi Kerja Terhadap Kinerja Karyawan Pada Pt. Bank Bpd Bali Cabang Ubud Jurnal Manajemen Universitas Udayana. 5(12).

Hotiana, N \& Febriansyah. (2018). Pengaruh Motivasi Dan Stres Kerja Terhadap Kinerja Pegawai (Studi Pada Bagian Kepegawaian dan Organisasi, Biro Umum, Kepegawaian dan Organisasi Kementrian Pariwisata RI) Jurnal Riset Manajemen dan Bisnis. 3(1).

Luthfi, I, R,. Susilo, H \& Riza, M, F. (2014). Pengaruh Motivasi Terhadap Kinerja Karyawan (Studi Pada PT Elsiscom Prima Karya, Kantor Perwakilan Surabaya) Jurnal Administrasi Bisnis Fakultas Ilmu Administrasi Universitas Brawijaya Malang. 13(1).

Riandy. (2016). Pengaruh Stres Kerja Terhada Kinerja Karyawan Pada PT. Borneo Laboratorium Inspeksi Dan Surveyor Service Samarinda Jurnal Administrasi Bisnis Fakultas Ilmu Sosial dan Politik Universitas Mulawarman. 4(4)

Sitepu, A, T. (2013). Beban kerja dan motivasi pengaruhnya terhadap kinerja karyawan pada PT. Bank Tabungan Negara Tbk Cabang Manado Jurnal Emba Fakultas Ekonomi dan Bisnis, Jurusan Manajemen Universitas Sam Ratulangi Manado. 4(1). 
Tasril. (2015). Pengaruh Stres Dan Motivasi Kerja Terhadap Kinerja Pegawai Pada Seksi Perencanaan Bidang Bina Marga Dinas Pekerjaan Umum Provinsi Riau Jurnal Ilmiah Ekonomi dan Bisnis Fakultas ekonomi Universitas Lancang Kuning. 12.(2) 